\title{
The Assignment of Knowledge Test Items to Functional and Cognitive Categories
}

\author{
10 \\ 10 \\ $\boldsymbol{\sigma}$ \\ Douglas B. Kuhn \\ HUMAN RESOURCES RESEARCH ORGANIZATION \\ for \\ Selection and Classification Technical Area \\ Lawrence M. Hanser, Chief \\ MANPOWER AND PERSONNEL RESEARCH LABORATORY \\ Newell K. Eaton, Director
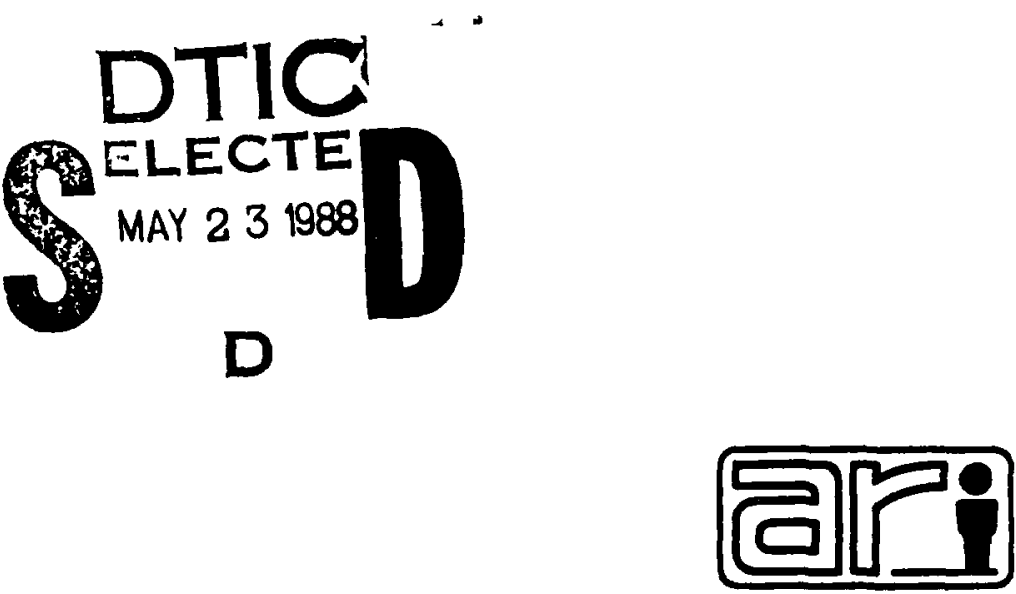 \\ U. S. Army \\ Research Institute for the Behavioral and Social Sciences \\ Apri 11988 \\ Approved for public relesse: distribution untimited.

$$
80001
$$




\title{
U. S. ARMY RESEARCH INSTITUTE FOR THE BEHAVIORAL AND SOCIAL SCIENCES
}

\author{
A Field Operating Agency under the Jurisdiction of the \\ Deputy Chief of Staff for Personnel
}

EDGAR M. LOHMSON

WM. DAAAY HENDERSON

Technied Directer

Colonch ins

Commander

Rescarch accomplished under contract to the Department of the Amry

Human Resources Rescarch Organization

Technical rovion by:

lieno F. Gast

Sidney Secha

Clinton a. Walker
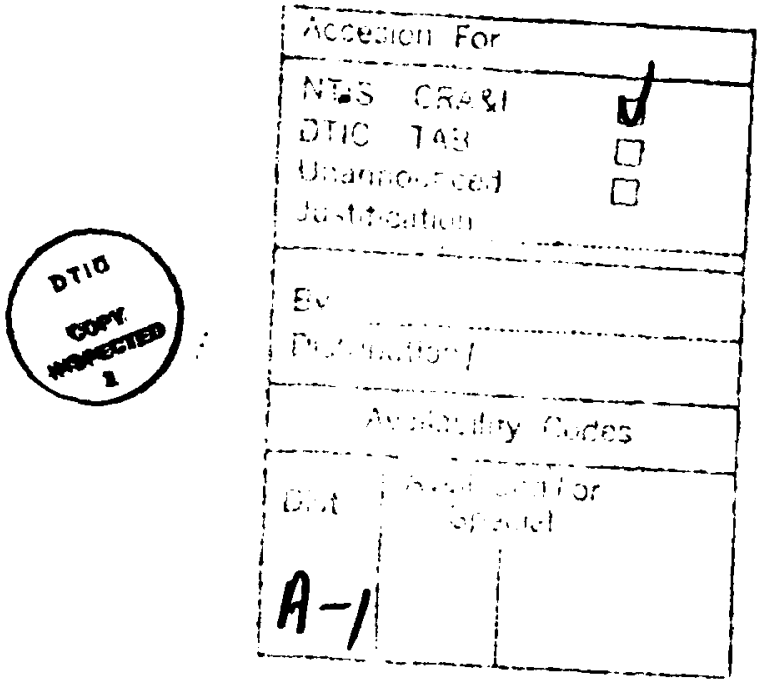

This report, us submirted by the contractor, hes been closed fer release to Defense Tuehnieal Informotion Cinter (DTIC) to comply with regulatory requirements. It has been given no primary distsibution other shen to OTI:

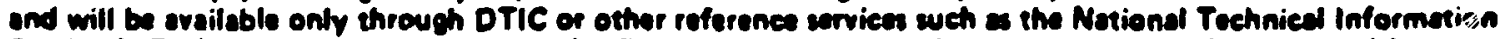
Servies (NTIS). The viem, epinigns, ond/or finding contained in this report are these of the euthor(s) e"d

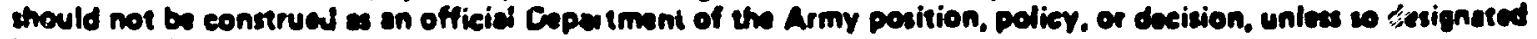
by other official doeumentetion. 
UNCLASSIFIED

SECURITY CLASSIFICATION OF THIS PAGE

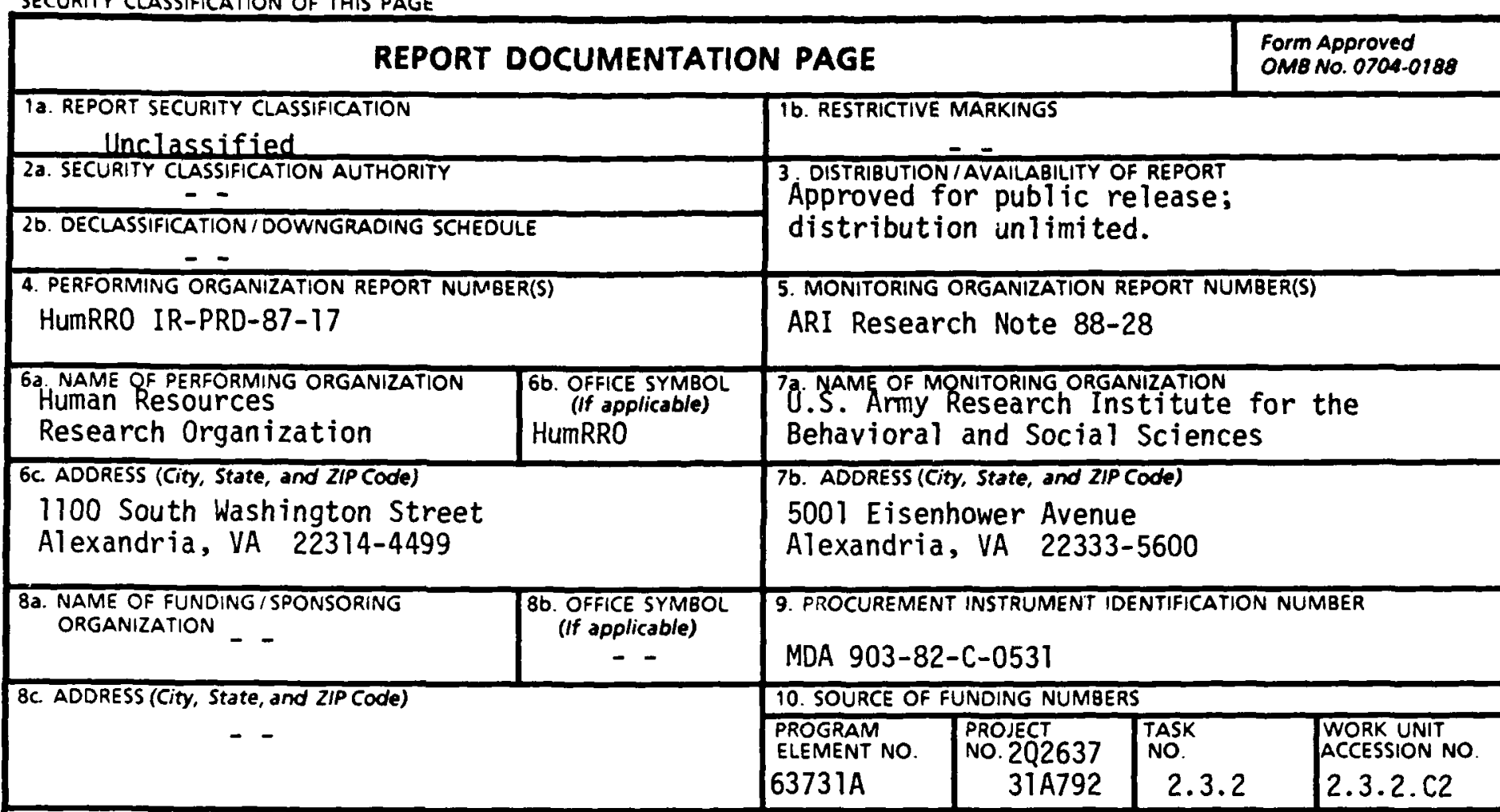

11. TITLE (Include Security Classification)

The Assignment of Knowledge Test Items to Functional and Cognitive Categories

12. PERSONAL AUTHOR(S)

Douglas B. Kuhn

\begin{tabular}{|l|l|l|l|l|}
\hline 13a. TYPE OF REPORT & 13b. TIME COVERED & 14. DATE OF REPORT (Year, MONth, Day) & 15. PAGE COUNT
\end{tabular}

Interim Renort FROM DCt. 85 TO Aug. 86 April 1988

69

16. SUPPLEMENTARY NOTATION Lawrence M. Hanser, contracting officer's representative

This research note is part of Project A: Improving the Selection, Classification,

(OVER)

\begin{tabular}{|c|c|c|c|c|}
\hline \multicolumn{3}{|c|}{ COSATI CODES } & \multicolumn{2}{|c|}{ 18. SUBJECT TERMS (Continue on reverse if necessary and identify by block number) } \\
\hline FIELD & GROUP & SUB-GROUP & Criterion Measures & Concurrent Validation, \\
\hline & & & Criterion Development & Knowledge Tests, \\
\hline & & & Criterion Space & Training, \\
\hline
\end{tabular}

19. ABSTRACT (Continue on reverse if necessary and identify by block number)

The research described in this note was conducted as part of Task 3 of Project A: Improving the Selection, Classification, and Utilization of Army Enlisted Personnel. Task 3 is specifically concerned with the development of training performance tests. This report describes the procedures used for assigning test items to functional and cognitive categories as a means of determining the part of the criterion space occupied by the test items. $k_{i}$,

\begin{tabular}{|c|c|c|}
\hline $\begin{array}{l}\text { 20. DISTRIBUTION/AVAILABILITY OF ABSTRACT } \\
\text { 冈UNCLASSIFIEDUNNLIMITED } \square \text { SAME AS RPT. }\end{array}$ & $\square$ DTIC USERS & $\begin{array}{l}\text { 21. ABSTRACT SECURITY CLASSIFICATION } \\
\text { Unclass if ied }\end{array}$ \\
\hline $\begin{array}{l}\text { 22a NAME OF RESPONSIBLE INDIVIDUAL } \\
\text { Lawrence } M \text {. Hanser }\end{array}$ & & \begin{tabular}{|l|l} 
22b. TELEPHONE (Include Area Code) & 22c. OFFICE SYMBOL \\
PERI-RS
\end{tabular} \\
\hline
\end{tabular}

DD Form 1473, JUN 86

Previous editions are obsolete.

SECURITY CLASSIFICATION OF THIS PAGE

i

UNCLASSIFIED 
ARI RESEARCH NOTE $88-28$

16. Supplementary Notation (continued)

and Utilization of Army Enlisted Personnel. (Human Resources Research Organization, American Institutes for Research, Personnel Decisions Research Institute, U.S. Army Research Institute for the Behavioral and Social Sciences) 


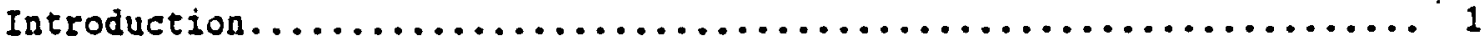

Overview of Project A.............................. 1

overview....................................... 2

Kethod ........................................

Functional Categories..............................

Cognitive Categories.................................8

Analyses and Results..................................

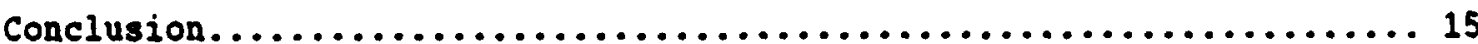

Appendix A. Functional Categories and Definitions...............16

B. Functional and Cognitive Categories with Test Items.......34

C. Batch A Three Factor Solution for Functional Categories... 56

D. Batch 2 Three Factor Solution for Functional Categories... 62

List of Figures and Tables

Figure 1. Batch $\boldsymbol{A}$ and Batch $z$ nos........................4

Table 1. Batch A MOS Duty Area Categories, Number, and Percent of Items in Bach Category......................... 6

2. Batch $\mathbf{z}$ MOS Duty Area Categories, Number and Percent of Items in Each Category......................... 7

3. Batch A KOS Cognitive Categories, Number and Percent of Itens in Each Category...........................10

4. Batch 2 Mos Cognitive Categories, Number, and Percent of Items in Bach Category..........................11

5. Batch A Duty Area Categories by Cognitive Categories....... 12

6. Batch Z Duty Area Categories by Cognitive Categories....... 13 


\section{IMTRODUCTION}

\section{BACKGROUND OF PROJECT A}

Project $A$ is a comprehensive long-range research and development prograin the U.S. Army has undertaken to develop an improved personnel selection and classification system for enlisted personnel. The Army's goal is to increase its effectiveness in matching first-tour enl isted manpower requirements with available personnel resources, through use of new and improved selection/classification tests that will validly predict carefully developed measures of job performance. The project addresses the Army's 675,000-person enlisted personnel system encompassing several hundred military occupations.

The program began in 1980, when the U.S. Army Research Institute (ARI) started planning the extensive research needed to develop the desired system. In 1982 ARI selected a consortium, led by Human Resources Research Organization (HumRRO) and including American Institutes for Research (AIR) and Personnel Decisions Research Institute (PDRI), to undertake the 9-year project. It is utilizing the services of 40 to 50 ARI and consortium researchers working collegially in a variety of professional specialties. The Project A objectives are to:

- Validate existing selection measures against both existing and project-developed criteria (including both Army-wide job performance measures based on rating scales, and direct hands-on measures of MOS-specific task performance).

- Develop and validate new selection and classification measures.

- Validate intermediate criteria such as training performance, as predictors of later criteria, such as job performance, so that better informed decisions on reassignment and promotion can be made throughout a soldier's career.

- Determine the relative utility to the Army of different performance levels across MOS.

In the second iteration, a Concurrent Validation design was executed with FY83/84 accessions. A "Preliminary Battery" of perceptual, spatial, temperament, interest, and biodata predictor measures was developed and tested with several thousand soldiers as they entered four MOS. The data from this sample were then used to refine the measures, with further exploration of content and format. The revised set of measures was field tested to assess reliabilities, "fakability," practice effects, and other factors. The resulting predictor battery, the "Trial Battery," was administered together with a comprehensive set of job performance indexes based on job knowledge tests, hands-on job samples, and performance rating measures, in the Concurrent validation during the summer and fall of 1985 . 
On the basis of testing experience, the "Trial Battery" was revised as the "Experimental Predictor Battery," which in turn is being administered in the Longitudinal Validation stage (third iteration), beginning in the late summer of 1986. All measures are being administered in a true predictive validity design. About 50,000 soldiers across 21 MOS will be included in the FY86-87 administration and subsequent first-tour measurement. About 3,500 of these soldiers are expected to be available for second-tour performance measurement in FY91. Three MOS have been added to the original $19(19 \mathrm{~K}, 29 \mathrm{E}, 96 \mathrm{~B})$, and one of the original MOS was dropped (76W).

Activities and progress during the first three years of Project $A$ were described in annual reports as follows: FY83 - ARI Research Report 1347 and its Technical Appendix, ARI Research Note 83-37; FY84 - ARI Research Report 1393 and related reports, ARI Technical Report 660 and ARI Research Note 85-14; FY85 - ARI Technical Report (in preparation) and ARI Research Note (in preparation). These reports list other publications on specific activities.

Other publications on specific activities during those years are listed in those annual reports. The annual report on project-wide activities during FY86 is presented in ARI Technical Report. The technical papers reproduced in this Research Note serve as additional documentation for various FY86 activities.

\section{Overview}

As described earlier by Campbell and Harris (1985) ${ }^{l}$, one of the major goals of the criterion component of Project $A$ is to describe a comprehensive model of performance for entry level skilled jobs that makes sense conceptually and empirically, and which would be useful in future work on performance measurement. The goal of the procedures described in this report is to develop a model of the school performance criterion space that can be applied to all MOS. The school performance tests may be used not only as criterion measures, but also as predictors since performance in training may be predictive of later job performance. By establishing such a relationship, the time required to validate selection predictors can be reduced from years to weeks or months. The purpose of this report is to describe the procedures used to identify that part of the criterion space occupied by the school performance measures developed by Task 3.

The criterion measure of school performance for Project $A$ is a knowledge test for each of 20 selected MOS. The twenty MOS were selected as a representative sample of the Army's occupational domain. The MOS selected are:

(1) High density MOS.

(2) Representative of aptitude areas measured by the ASVAB area composites.

\footnotetext{
TCampbell, J. P. and Harris, J. H. (1985, August) Criterion reduction and combination via a participative decision making panel. Paper presented at symposium entitled, "Building a composite measure of soldier performance." American Psychological Association, Los Angeles.
} 
(3) High priority MOS (as rated by the Army in the event of a national emergency).

(4) Representative of the Army's designated Career Management Fields.

(S) Representative of the jobs most crucial to the Army's mission.

The MOS are listed in figure 1. They are divided into two Batches, A and 2 . MOS in Batch $A$ are those for which a full range of criterion measures was developed in Tasks 3, 4, and 5. Batch $Z$ MOS have a subset of the full range of criterion measures made up of measures developed in Task 3 and 4.

The school performance knowledge tests are multiple-choice, paperand-pencil tests containing 105 to 181 items each and are designed to assess the information or knowledge acquired during school training. More than 3,000 items were developed. In order to describe the items in meaningful terms, they must be reduced to categories based on their similarities. There are many levels of specificity at which the criterion space can be defined. At one extreme, the criterion space could be defined as the sum of all the items. This would reduce the criterion space too much. At the other extreme, the criterion space can be defined on an MOS-by-MOS basis as the sum of the items for each MOS. This reduces the criterion space too little. In an effort to define the criterion space as something in between these extremes, that would fit all the MOS, three categorization schemes were developed and evaluated. Two of the categorization schemes are based on functional categories and the third is based on a cognitive categorization. The following sections describe the procedures and outcomes of all three categorizations.

\section{METHOD}

\section{Functional Categories}

The first categorization scheme separated the items into functional categories based on the items' content. A functional category is defined by the specific knowledges, skills, and equipment required to demonstrate expertise in a given area. Examples of functional categories are: First Aid, Weapons, and Customs \& Laws.

The development of functional categories required content analyzing the test items. As a starting point, categories developed for Task 5 job knowledge tests were used. The Task 5 job knowledge tests are multiplechoice, paper-and-pencil tests designed to measure on-the-job proficiency. The job knowledge test domain was identified through the use of the Army Occupational Survey (AOS), the Soldier's Manual of Common Tasks, MOSspecific Soldier's Manuals, and MOS Proponent Agency input. Subject Matter Experts (SME) provided judgments of tasks for criticality, difficulty, and similarity, and separate panels of SME in each MOS used those judgements to select 30 tasks in each Batch $A$ MOS for which to have performance measures developed. The Task 3 school knowledge test items were sorted into these job knowledge categories by six Task 3 researchers working independently. 
Batch A

$11 B$

13B Towed

13B Self Propelled

$19 E$

$31 \mathrm{C}$

$63 \mathrm{~B}$

$64 C$

711

$91 \mathrm{~A}$

95B

Batch Z

12B

165

$27 E$

51B

$54 E$

$55 B$

$67 \mathrm{~N}$

$76 \mathrm{~W}$

$76 Y$

$94 B$
Infantryman

Cannon Crewman

Cannon Crewman

Tank Crewman

Single Channel Radio Operator

Light Wheel Vehicle Mechanic

Motor Transport Operator

Administrative Specialist

Medical Specialist

Military Police

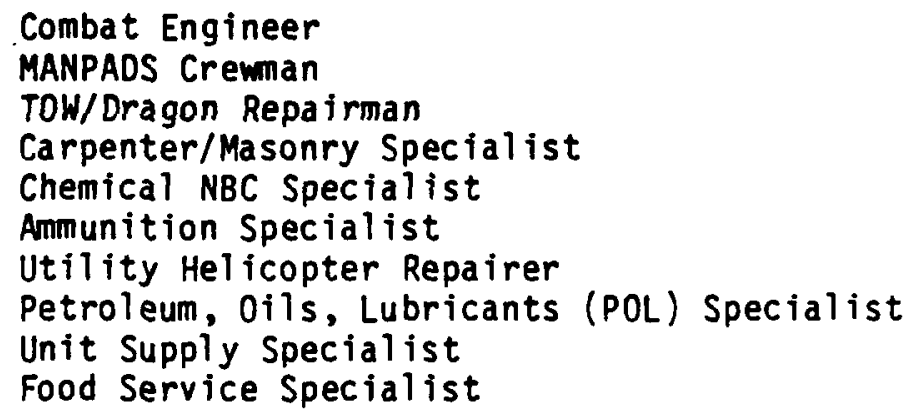

Figure 1. Batch $A$ and Batch $Z$ mOS 
Categories for Batch $Z$ MOS test items were developed using the Batch $A$ categories as a model. Functional categories from Batch $A$ that were common to Batch $Z$ MOS were retained. The remaining Batch $Z$ categories were developed using the Army Occupational Survey (AOS) for each MOS. The AOS provides a breakdown of duty areas and tasks which comprise each duty area. Duty areas from the AOS were collapsed to form the various functional categories for each MOS. Batch $Z$ test items were then sorted by six Task 3 researchers.

Although most items could be assigned using only category titles, two problems became evident. First, certain items common to most tests (i.e., basic training items) were consistently assigned to different categories by the researchers. For example, a test item referring to the administration of an antidote to a nerve agent casualty was considered a "First Aid" item by some researchers and an "NBC" (Nuclear/Biological/Chemical Operations) item by others. Clearer definitions of each functional category were written which specified, by example, how items falling reasonabiy into more than one category were to be sorted.

The second problem was the categorization of MOS-specific items. The first categorization attempt had relatively few categories for items to be assigned. This caused items relating to MOS-specific tasks to be assigned to "common" task clusters. For example, nearly all of the Task 3 tests have items referring to the M16 rifle. These items were consistently (and appropriately) assigned to the "Weapons" category. However, some MOS have training on a specific weapon system. For example, the $13 B$ MOS is the only MOS which uses howitzers in addition to weapons such as the M16 rifle. Since there was not a "Howitzer" category, the howitzer items were assigned to the "Weapons" category. Thus, in order to preserve MOS-specific training areas, additional MOS-specific categories were added (e.g., Prepare, operate, maintain howitzer and ammunition) and defined.

Following the writing of clearer definitions and adding of some MOSspecific categories, the items were re-sorted. The functional categories and their definitions are provided in Appendix $A$. Separate Batch $A$ and Batch $Z$ categories were used since additional criterion measures are available (e.g., hands-on, job performance tests) for the Batch A MOS which may fit this categorization scheme. The number of items in each category across MOS is shown in Tables 1 and 2.

As mentioned earlier, our goal was to define the criterion space occupied by the school knowledge tests. The second categorization scheme was an attempt to reduce the number of functional categories required to define the criterion space. The functional categories were combined rationally into four larger categories based on their content. The reduced categories and a definition of each are provided below. 


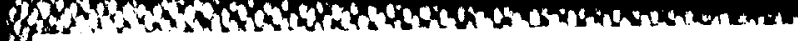

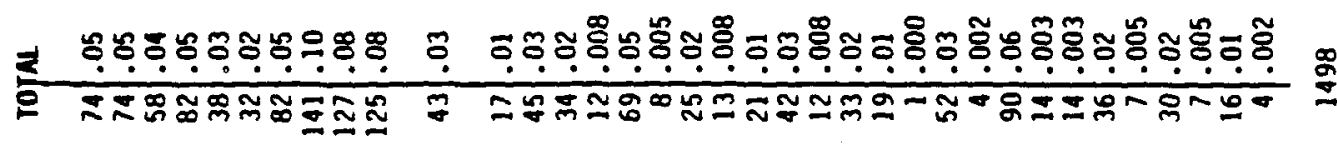

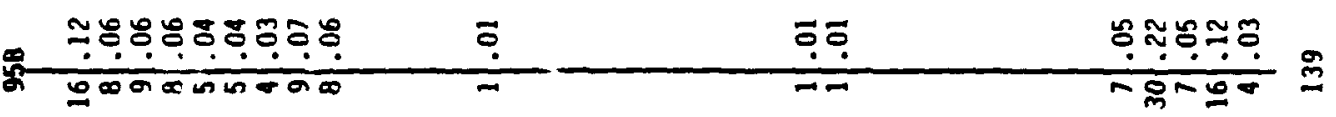

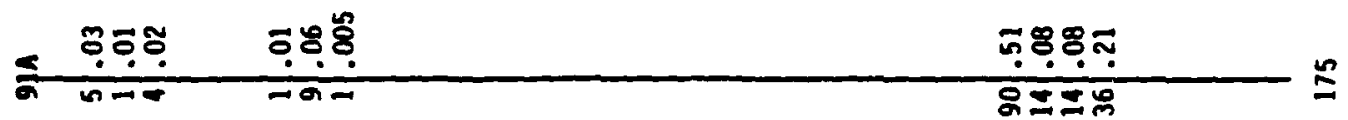

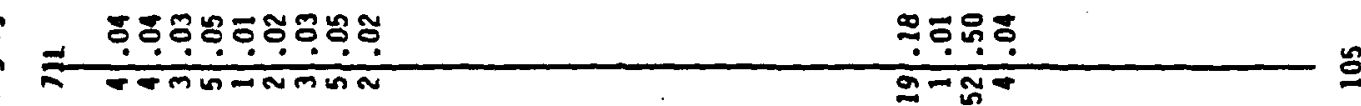

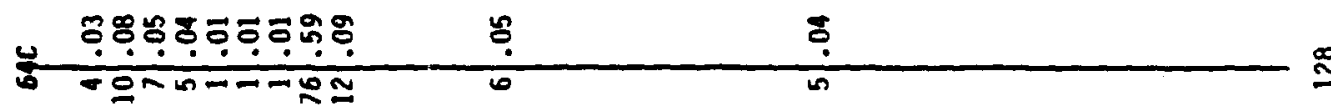

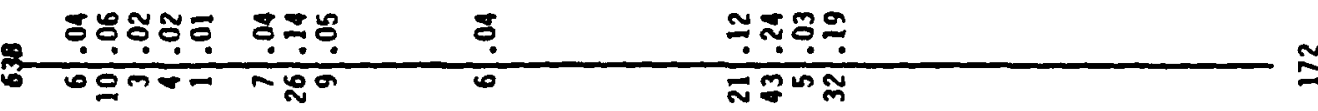

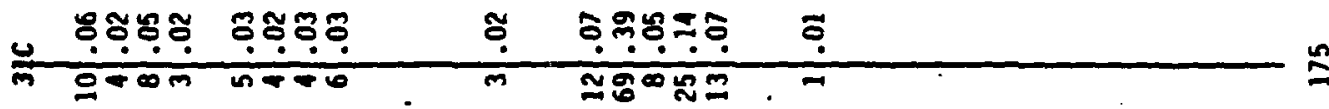

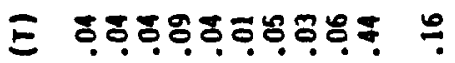

愚

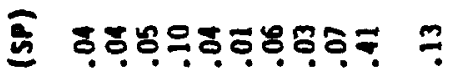

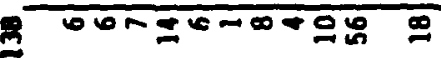

- 우웅둥유웅

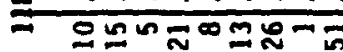

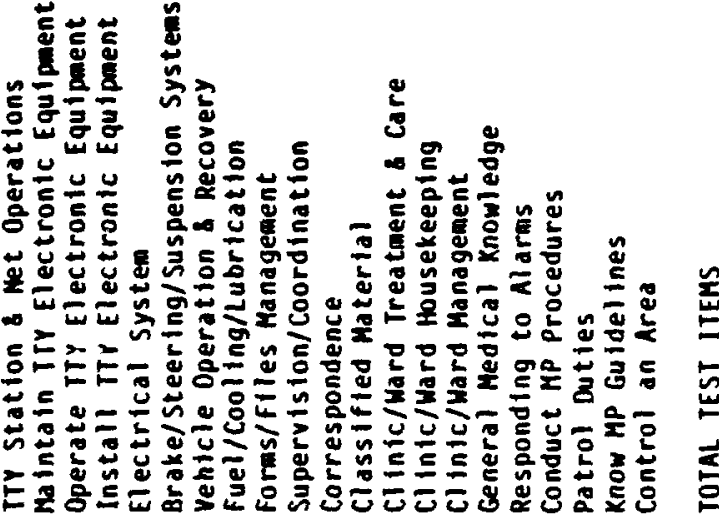




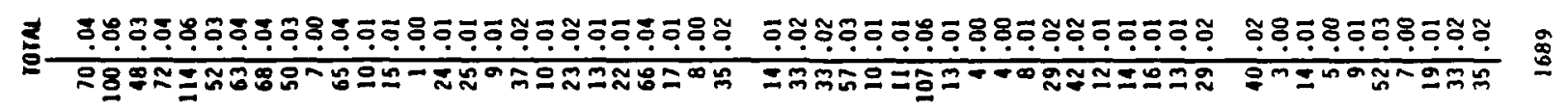

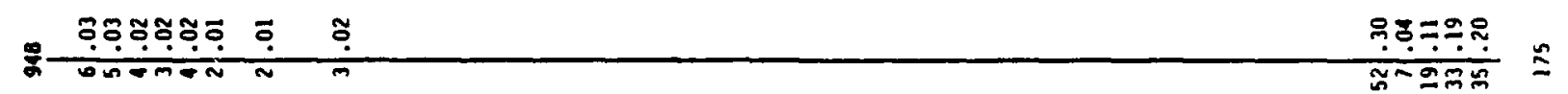

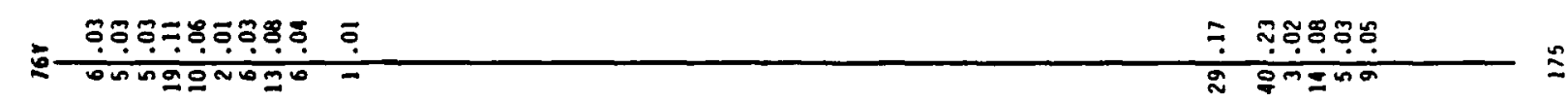
害

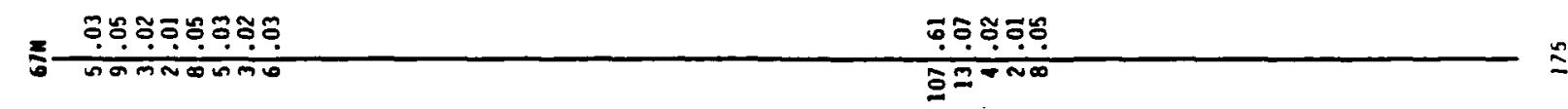

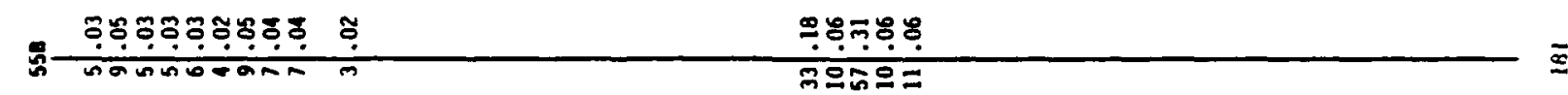

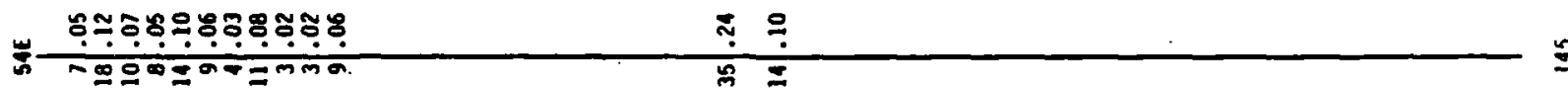

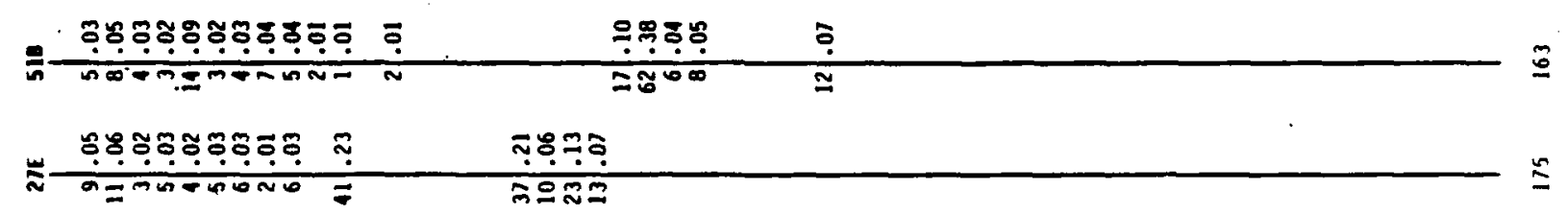

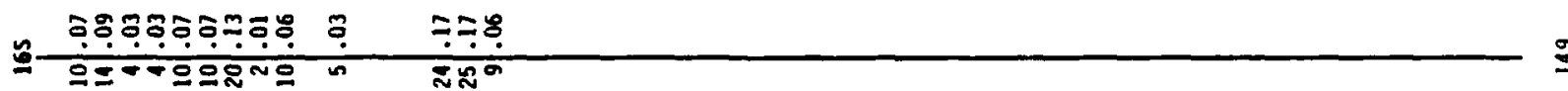

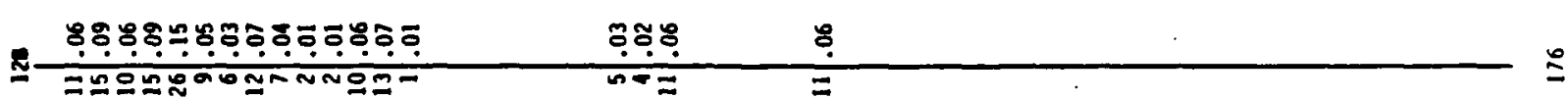

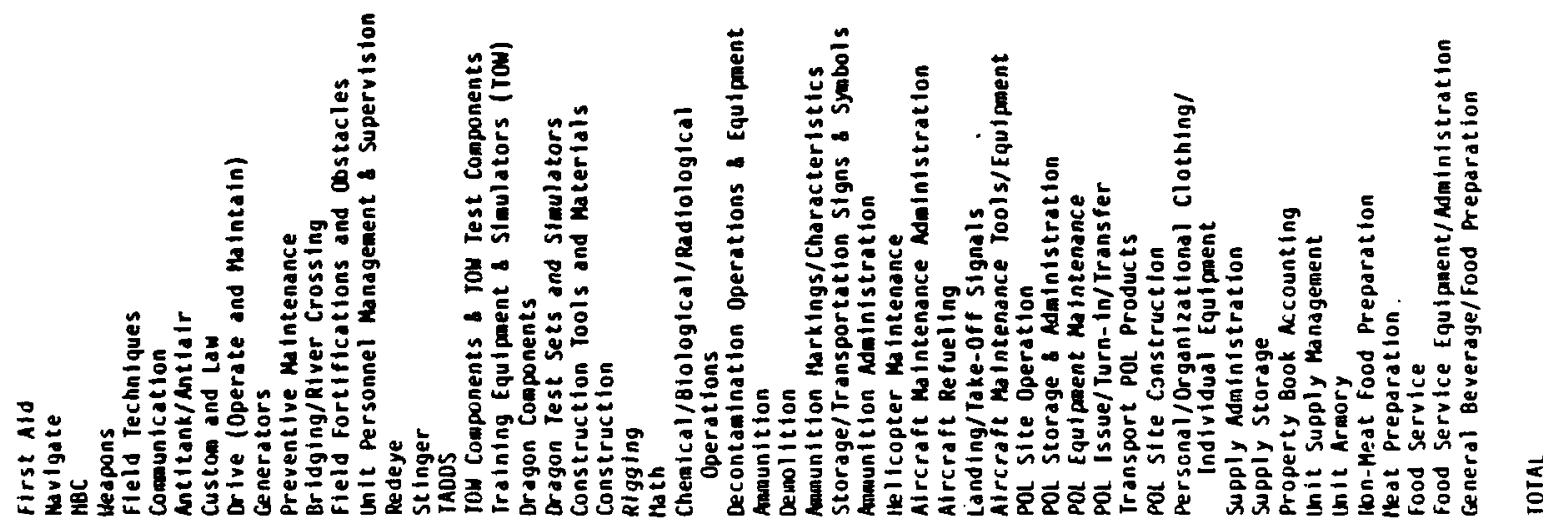


Field Skills

Consists of items whose primary purpose is to indicate knowledge of field techniques, navigation, and communications in a field environment. Also includes items related to the operation and maintenance of wheeled vehicles and preventive maintenance requirements and activities performed on any equipment or vehicles (excluding weapons).

Weapons Operation and Maintenance

Consists of items whose primary purpose is to indicate knowledge about the maintenance, preparation, and firing of small arms. Al so includes items related to the identification of friendly and enemy aircraft and tanks and techniques for neutralizing enemy tank and air threats.

Survival

Consists of items whose primary purpose is to indicate knowledge of first aid, NBC clothing, equipment, and procedures, and SOP governing the treatment of enemy personnel, engaging the enemy, and the conduct of military protocol and ceremony. Also includes guard duty and physical readiness.

Technical Knowledge

Consists of items whose primary purpose is to indicate knowledge of skills required for carrying out the mission of each MOS. Includes all items referring to unique MOS training and exercises.

The functional categories in each of the Field Skills, Weapons Operation and Maintenance, Survival, and Technical Knowledge categories (FWST) are shown in Appendix $B$.

\section{Cognitive Categories}

As an alternative to using functional categories to define the criterion space, a third categorization scheme was developed to sort items according to the cognitive processes required to demonstrate the knowledge called for by the correct test option. Four cognitive categories were identified based on the complexity of the cognitive process required to answer each test item. This scheme could be used independently or in combination with the functional categories. These categories and their definitions are provided below.

KI - recognition of objects and words, recall of facts and principles. Memory is the main underlying component of this knowledge category. 
K2 - recall of procedures and steps of procedures. Memory is crucial here, too. However, recalling procedures involves retrieving more information from long-term memory and requires placing this information into a specific context and, hence, is more cognitively demanding. This type of recall may be differentially predictable from the simple recall of $\mathrm{KL}$.

K3 - application of principles, use of information to make inferences or decisions. This category subsumes the higher orders of cognition (e.g., concept learning, problem solving) and is characterized by active processing of information. It implies using textual and graphic information provided, interpreting it correctly, and selecting a course of action as a result. This category includes knowledge items that require cognitive manipulations of visual and spatial information.

K4 - inferring from a general principle. Some knowledge items can be answered (i.e., some test options can be rejected) by inference from a general principle without the need to recall or to know specific facts. For example, one might be able to answer a question (or eliminate obvious wrong options) concerning wounds by understanding the general principle of "sterile procedures." If so, this is an ability that is probably differentially predictable from $k 3$.

Using four to five-raters working independently, the test items were sorted into the four categories. Rater agreement ranged from $78.1 \%$ to 91.7\% for each test. The test items were assigned to categories according to the modal response of the raters. For example, if three raters assigned an item to $K 1$ and two raters assigned the $i$ tem to $K 2$, then the item was categorized as $\mathrm{Kl}$. If the item had more than one mode, it was discussed $l y$ the raters in order to reach a consensus as to the proper categorization for the item.

Tables 3 and 4 provide listings of the number and percent of $i$ tems placed into each category and the percent of rater agreement across MOS for Batch $A$ and Batch $Z$ MOS. Tables 5 and 6 show the number of Batch $A$ and Batch $Z$ MOS items in each functional category with the cognitive categories.

\section{Analyses and Results}

The functional and cognitive categories were factor analyzed to determine whether further reductions in the number of categories or al ternative combinations of the categories would be useful in explaining the criterion space. Five factor analyses were computed for each MOS:

(1) Functional categories.

(2) FWST categories.

(3) Cognitive categories.

(4) Functional categories with cognitive categories.

(5) FWST categories with cognitive categories. 
TABLE 3

Batch A MOS Cognitive Categories, Number, and Percent of Items in Each Category

\begin{tabular}{|c|c|c|c|c|c|c|c|}
\hline MOS & \% Agree & $\begin{array}{l}N \text { of } \\
\text { Ra ters }\end{array}$ & $\begin{array}{l}N \& \% \\
\text { in } K 1\end{array}$ & $\begin{array}{l}N \& \% \\
\text { in } K 2\end{array}$ & $\begin{array}{l}N \& \% \\
\text { in } k 3\end{array}$ & $\begin{array}{l}N \& \% \\
\text { in } K 4\end{array}$ & $\begin{array}{l}\text { Total } \\
\text { It ems }\end{array}$ \\
\hline $11 \mathrm{~B}$ & 81.9 & 5 & $\begin{array}{r}119 \\
79.3\end{array}$ & $\begin{array}{r}25 \\
16.7\end{array}$ & $\begin{array}{r}4 \\
2.7\end{array}$ & $\begin{array}{r}2 \\
1.3\end{array}$ & 150 \\
\hline $13 B-S P$ & 82.2 & 4 & $\begin{array}{r}96 \\
70.5\end{array}$ & $\begin{array}{r}31 \\
22.8\end{array}$ & $\begin{array}{r}4 \\
2.9\end{array}$ & $\begin{array}{r}5 \\
3.7\end{array}$ & 136 \\
\hline $13 B-T$ & 84.6 & 4 & $\begin{array}{r}113 \\
72.4\end{array}$ & $\begin{array}{r}33 \\
21.2\end{array}$ & $\begin{array}{r}5 \\
3.2\end{array}$ & $\begin{array}{r}5 \\
3.2\end{array}$ & 156 \\
\hline $19 E$ & 85.5 & 4 & $\begin{array}{r}115 \\
71\end{array}$ & $\begin{array}{r}38 \\
23.4\end{array}$ & $\begin{array}{r}7 \\
4.3\end{array}$ & $\begin{array}{r}2 \\
1.2\end{array}$ & 162 \\
\hline $31 C$ & 81.6 & 4 & $\begin{array}{r}124 \\
70.9\end{array}$ & $\begin{array}{r}36 \\
20.6\end{array}$ & $\begin{array}{r}11 \\
6.3\end{array}$ & $\begin{array}{r}4 \\
2.3\end{array}$ & 175 \\
\hline $63 B$ & 83.6 & 4 & $\begin{array}{r}94 \\
54.7\end{array}$ & $\begin{array}{r}56 \\
32.6\end{array}$ & $\begin{array}{l}19 \\
11\end{array}$ & $\begin{array}{r}3 \\
1.7\end{array}$ & 172 \\
\hline $64 C$ & 81.6 & 4 & $\begin{array}{r}75 \\
58.6\end{array}$ & $\begin{array}{r}37 \\
28.9\end{array}$ & $\begin{array}{r}4 \\
3.1\end{array}$ & $\begin{array}{r}12 \\
9.4\end{array}$ & 128 \\
\hline $71 L$ & 79.3 & 4 & $\begin{array}{r}65 \\
61.9\end{array}$ & $\begin{array}{r}33 \\
31.4\end{array}$ & $\begin{array}{r}6 \\
5.7\end{array}$ & $\begin{array}{l}1 \\
1\end{array}$ & 105 \\
\hline $91 A$ & 82.7 & 4 & $\begin{array}{r}126 \\
72\end{array}$ & $\begin{array}{r}40 \\
22.5\end{array}$ & $\begin{array}{r}2 \\
1.1\end{array}$ & $\begin{array}{l}7 \\
4\end{array}$ & 175 \\
\hline $95 B$ & 78.1 & 4 & $\begin{array}{r}81 \\
58.3\end{array}$ & $\begin{array}{r}42 \\
30.2\end{array}$ & $\begin{array}{r}11 \\
7.9\end{array}$ & $\begin{array}{r}5 \\
3.6\end{array}$ & 139 \\
\hline TOTAL & & & $\begin{array}{l}1008 \\
67.3\end{array}$ & $\begin{array}{r}371 \\
24.8\end{array}$ & $\begin{array}{r}73 \\
4.9\end{array}$ & $\begin{array}{r}46 \\
3.1\end{array}$ & 1498 \\
\hline
\end{tabular}


TABLE 4

Batch $Z$ inos Cognitive Categories, Number, and Percent of Items in Each Category

\begin{tabular}{|c|c|c|c|c|c|c|c|}
\hline MOS & \% Agree & $\begin{array}{l}\text { N of } \\
\text { Raters }\end{array}$ & $\begin{array}{l}N \& \% \\
\text { in } K I\end{array}$ & $\begin{array}{l}N \& \% \\
\text { in } K 2\end{array}$ & $\begin{array}{l}N \& \% \\
\text { in } k 3\end{array}$ & $\begin{array}{l}N \& \% \\
\text { in } K 4\end{array}$ & $\begin{array}{l}\text { Total } \\
\text { Items }\end{array}$ \\
\hline $12 \mathrm{~B}$ & 87.8 & 5 & $\begin{array}{r}146 \\
83\end{array}$ & $\begin{array}{r}19 \\
10.8\end{array}$ & $\begin{array}{r}7 \\
4.0\end{array}$ & $\begin{array}{r}4 \\
2.3\end{array}$ & 176 \\
\hline $16 S$ & 84.6 & 5 & $\begin{array}{r}122 \\
81.8\end{array}$ & $\begin{array}{r}16 \\
10.7\end{array}$ & $\begin{array}{r}8 \\
5.4\end{array}$ & $\begin{array}{r}3 \\
2.0\end{array}$ & 149 \\
\hline $27 E$ & 84.2 & 5 & $\begin{array}{r}140 \\
80.0\end{array}$ & $\begin{array}{r}20 \\
11.4\end{array}$ & $\begin{array}{r}15 \\
8.6\end{array}$ & $\begin{array}{l}0 \\
0\end{array}$ & 175 \\
\hline $51 B$ & 87.2 & 5 & $\begin{array}{r}127 \\
77.9\end{array}$ & $\begin{array}{r}14 \\
8.6\end{array}$ & 12.9 & $\begin{array}{r}1 \\
0.6\end{array}$ & 163 \\
\hline $54 \mathrm{E}$ & 84.3 & 5 & $\begin{array}{r}112 \\
77.2\end{array}$ & $\begin{array}{r}17 \\
11.7\end{array}$ & $\begin{array}{r}14 \\
9.7\end{array}$ & $\begin{array}{r}2 \\
1.4\end{array}$ & 145 \\
\hline $55 B$ & 91.7 & 5 & $\begin{array}{r}157 \\
87.3\end{array}$ & $\begin{array}{r}17 \\
9.4\end{array}$ & $\begin{array}{r}6 \\
2.8\end{array}$ & 0.5 & 181 \\
\hline $67 N$ & 88.0 & 5 & $\begin{array}{r}152 \\
86.9\end{array}$ & $\begin{array}{r}21 \\
12.0\end{array}$ & $\begin{array}{r}2 \\
1.1\end{array}$ & $\begin{array}{l}0 \\
0\end{array}$ & 175 \\
\hline $76 \mathrm{~W}$ & 87.7 & 5 & $\begin{array}{r}151 \\
86.3\end{array}$ & $\begin{array}{r}14 \\
8.0\end{array}$ & $\begin{array}{r}7 \\
4.0\end{array}$ & $\begin{array}{r}3 \\
1.7\end{array}$ & 175 \\
\hline $76 Y$ & 82.7 & 5 & $\begin{array}{r}145 \\
82.9\end{array}$ & $\begin{array}{r}22 \\
12.6\end{array}$ & $\begin{array}{r}3 \\
1.7\end{array}$ & $\begin{array}{r}5 \\
2.9\end{array}$ & 175 \\
\hline $94 B$ & 86.6 & 5 & $\begin{array}{r}144 \\
82.3\end{array}$ & $\begin{array}{r}18 \\
10.3\end{array}$ & $\begin{array}{r}13 \\
7.4\end{array}$ & $\begin{array}{l}0 \\
0\end{array}$ & 175 \\
\hline TOTAL & 86.4 & & $\begin{array}{l}1396 \\
82.6\end{array}$ & $\begin{array}{r}177 \\
10.5\end{array}$ & $\begin{array}{r}96 \\
5.7\end{array}$ & $\begin{array}{r}18 \\
1.1\end{array}$ & 1689 \\
\hline
\end{tabular}


TABLE 5

Batch A MOS Duty Area Categories by Cognitive Categories

First Aid

Navigate

NBC

Weapons

Field Techniques

Communication

Antitank/Antiair

Custom and Law

Drive (Operate \& Maintain)

Prepare, Operate, Maintain Howitzer \& Ammo

Operate Howitzer Sights \&

Alignment Devices

Preventive Maintenance

Tank Gunnery

Operate Tanks

Generators

TTY Station \& Net Operations

Ma inta in TTY Electronic Equipment

Operate TTY Electronic Equipment

Install TTY Electronic Equipment

Electrical System

Brake/Steering/Suspension Systems

Vehicle Operation \& Recovery

Fuel/Cooling/Lubrication

Forms/Files Management

Supervision/Coordination

Correspondence

Classified Material

Clinic/Ward Treatment \& Care

Cl inic/Ward Housekeeping

Clinic/Ward Management

General Medical Knowledge

Responding to Alarms

Conduct MP Procedures

Patrol Duties

Know MP Guidel ines

Control an Area

TOTAL TEST ITEMS

\begin{tabular}{rrrrr} 
K1 & K2 & K3 & K4 & TOTAL \\
\hline 48 & 23 & 1 & 2 & 74 \\
61 & 1 & 12 & 0 & 74 \\
37 & 16 & 1 & 4 & 58 \\
41 & 35 & 6 & 0 & 82 \\
97 & 12 & 0 & 18 & 117 \\
30 & 5 & 3 & 0 & 38 \\
21 & 8 & 3 & 0 & 32 \\
59 & 17 & 0 & 6 & 82 \\
82 & 46 & 4 & 9 & 141 \\
99 & 25 & 1 & 0 & 125 \\
& & & & \\
30 & 11 & 2 & 0 & 43 \\
& & & & \\
12 & 1 & 4 & 0 & 17 \\
25 & 17 & 3 & 0 & 45 \\
23 & 6 & 3 & 2 & 34 \\
5 & 6 & 1 & 0 & 12 \\
53 & 9 & 7 & 0 & 69 \\
5 & 3 & 0 & 0 & 8 \\
22 & 3 & 0 & 0 & 25 \\
8 & 4 & 1 & 0 & 13 \\
9 & 8 & 4 & 0 & 21 \\
17 & 20 & 6 & 0 & 43 \\
7 & 6 & 0 & 0 & 13 \\
16 & 13 & 4 & 0 & 33 \\
10 & 8 & 0 & 1 & 19 \\
1 & 0 & 0 & 0 & 1 \\
39 & 11 & 2 & 0 & 52 \\
4 & 0 & 0 & 0 & 4 \\
57 & 28 & 2 & 3 & 90 \\
11 & 2 & 0 & 1 & 14 \\
10 & 4 & 0 & 0 & 14 \\
36 & 0 & 0 & 0 & 36 \\
4 & 3 & 0 & 0 & 7 \\
17 & 10 & 2 & 1 & 30 \\
3 & 4 & 0 & 0 & 7 \\
9 & 6 & 1 & 0 & 16 \\
3 & 1 & 0 & 0 & 4 \\
1008 & 371 & 73 & 46 & 1498
\end{tabular}


TABLE 6

Batch 2 mos Duty Area Categories by Cognitive Categories

First Aid

Navigate

NBC

Weapons

Field Techniques

Communication

Anti tank/ Antia ir

Custom and Law

Drive (Operate \& Maintain)

Generators

Preventive Maintenance

Bridging/River Crossing

Field Fortifications and obstacles

Unit Personnel Management and Supervision

Redeye

Stinger

TAADS

TOW Components \& TOW Test Components

Training Equipment \& Simulators (TOW)

Dragon Components

Oragon Test Sets \& Simulators

Construction Tools \& Materials

Construction

Rigging

Math

Chenical/Biological/Radiological Operations

Decontamination Operations \& Equipment

Amunition

Demolition

Ammunition Markings/Characteristics

Storage/Transportation Signs \& Symbols

Ammunition Administration

Hel icopter Maintenance

Aircraft Maintenance Administration

Atrcraft Refueling

Landing/Take-off Signals

POL Site Operation

POL Storage \& Administration

POL Equitpment Maintenance

POL Issue/Turn-in/Transfer

Transport POL Products

POL Site Construction

Aircraft Maintenance Tools/Equiment

Personal/Organizational Clothing/ Individual Equipment

Supply Administration

Supply Storage

Property Book Accounting

Unit Supply Management

Unit Armory

Mon-meat Food Preparation

Meat Preparation

Food Service

Food Service Equipment/Administration

General Beverage/Food Preparation

TOTAL

\begin{tabular}{|c|c|c|c|c|}
\hline $\mathbf{K} \mathbf{I}$ & K2 & K3 & K4 & TOTAL \\
\hline $\begin{array}{r}41 \\
79 \\
35 \\
54 \\
106 \\
41 \\
44 \\
52 \\
33 \\
5 \\
50 \\
10 \\
15 \\
1 \\
23 \\
23 \\
8 \\
30 \\
9 \\
19 \\
13 \\
14 \\
57 \\
17 \\
0 \\
27\end{array}$ & $\begin{array}{r}23 \\
1 \\
13 \\
18 \\
4 \\
6 \\
13 \\
10 \\
12 \\
2 \\
1 \\
0 \\
0 \\
0 \\
1 \\
0 \\
1 \\
7 \\
1 \\
3 \\
0 \\
2 \\
5 \\
0 \\
0 \\
3\end{array}$ & $\begin{array}{r}6 \\
20 \\
0 \\
0 \\
0 \\
5 \\
5 \\
0 \\
0 \\
0 \\
13 \\
0 \\
0 \\
0 \\
0 \\
0 \\
0 \\
0 \\
0 \\
1 \\
0 \\
6 \\
4 \\
0 \\
8 \\
5\end{array}$ & $\begin{array}{l}0 \\
0 \\
0 \\
0 \\
0 \\
4 \\
0 \\
0 \\
0 \\
5 \\
5 \\
0 \\
0 \\
1 \\
0 \\
0 \\
0 \\
0 \\
1 \\
1 \\
0 \\
0\end{array}$ & $\begin{array}{r}70 \\
100 \\
48 \\
72 \\
114 \\
52 \\
62 \\
68 \\
50 \\
7 \\
65 \\
10 \\
15 \\
1 \\
25 \\
25 \\
9 \\
37 \\
10 \\
23 \\
13 \\
22 \\
66 \\
17 \\
8 \\
35\end{array}$ \\
\hline $\begin{array}{r}11 \\
28 \\
33 \\
57 \\
10 \\
9 \\
96 \\
13 \\
4 \\
4 \\
25 \\
37 \\
10 \\
12 \\
16 \\
11 \\
6 \\
28\end{array}$ & $\begin{array}{r}2 \\
3 \\
0 \\
0 \\
0 \\
0 \\
11 \\
0 \\
0 \\
0 \\
4 \\
1 \\
2 \\
2 \\
0 \\
2 \\
2 \\
0\end{array}$ & $\begin{array}{l}0 \\
2 \\
0 \\
0 \\
0 \\
2 \\
0 \\
0 \\
0 \\
0 \\
0 \\
4 \\
0 \\
0 \\
0 \\
0 \\
0 \\
0\end{array}$ & $\begin{array}{l}1 \\
0 \\
0 \\
0 \\
0 \\
0 \\
0 \\
0 \\
0 \\
0 \\
0 \\
0 \\
0 \\
0 \\
0 \\
0 \\
0 \\
1\end{array}$ & $\begin{array}{r}14 \\
33 \\
33 \\
57 \\
10 \\
11 \\
107 \\
13 \\
4 \\
4 \\
29 \\
42 \\
12 \\
14 \\
16 \\
13 \\
8 \\
29\end{array}$ \\
\hline $\begin{array}{r}37 \\
2 \\
12 \\
5 \\
9 \\
46 \\
7 \\
18 \\
26 \\
22\end{array}$ & $\begin{array}{l}2 \\
1 \\
2 \\
0 \\
0 \\
5 \\
0 \\
1 \\
7 \\
2\end{array}$ & $\begin{array}{l}1 \\
0 \\
0 \\
0 \\
0 \\
1 \\
0 \\
0 \\
0 \\
11\end{array}$ & $\begin{array}{l}0 \\
0 \\
0 \\
0 \\
0 \\
0 \\
0 \\
0 \\
0 \\
0\end{array}$ & $\begin{array}{r}40 \\
3 \\
14 \\
5 \\
9 \\
52 \\
7 \\
19 \\
33 \\
35\end{array}$ \\
\hline 1396 & 178 & 96 & 19 & 1689 \\
\hline
\end{tabular}


The three factor solution for the functional categories proved the most interpretable and useful.

The three factor solution showed that, for each Mns, two factors consistently emerged: Common soldiering skills and MOS specific ones. The third factor differed by MOS and usually consisted of those functional categories having the fewest items. The three factor analysis results are shown for Batch $A$ and Batch $Z$ MOS in Appendixes $C$ and $D$, respectively.

The three factor solution for the functional categories was consistent across MOS. The MOS did have different functional categories, however, within the common and MOS specific factors. Since our goal was to develop a model of the school performance criterion space that applied to all MOS, we did additional analyses on the three factor solution.

The functional category of Antitank/Antiair proved to be particularly unstable using the three factor solution, loading on different factors across MOS without any apparent rationale.

After reviewing the test items in Antitank/Antiair, we decided to split this category into two. Some of the items referred to the identification of enemy tanks and aircraft while the remaining items referred to engaging enemy tanks and aircraft. Thus, the new category of ID Targets was added consisting of those identification items. The remaining engagement items then made up the Antitank/Antiair category.

Factor analyses were conducted again on all of the functional categories and factor solutions consisting of three to nine factors were evaluated for each MOS. This evaluation of the factor structure was conducted by Project A staff scientists, task leaders, and the principal scientist. Using the various factor solutions and rational interpretation of the functional categories, a six factor solution emerged. These factors define the criterion space for the school tests and is applicable of all of the MOS. Thus, a single model of school performance can be used. The six factors and their definitions are provided below.

Communication $=$ Communication

Vehicles = Drive, Preventive Maintenance, and Vehicle Operation and Recovery

Basic Skills = Navigate, Weapons, Field Techniques, Custom and Law, and Antitank/Antiair Weapons

ID Target $=$ ID Target

Technical = Consists of items referring to unique MOS training and exercises.

Safety $=$ First Aid and NBC 


\section{Conclusion}

These new functional categories define the criterion scores for the school tests. They will be used with criterion scores derived for the other criterion measures to describe the Project A model of performance for data collected during the Concurrent Validation.

Based on factor analytic information, it was possible to evaluate the functional and cognitive categorization schemes. The cognitive categorization proved to be less effective in defining the criterion space. This was probably due to the large number of items in KI (67\% in Batch A and $82 \%$ in Batch Z).

The functional categorization scheme demonstrates the content of each school test for each MOS. If the same categorization scheme can be used for the Task 5 job performance measures, it may be possible to predict scores in job performance categories from scores in training performance categories. 


\section{Appendix A}

Functional Categories and Definitions 
BATCH A

$$
\begin{array}{lrrrrrrrrrr}
11 B & -C A & -S P b & -T^{C} & & & & & & & \\
13 B & 13 B & 13 B & 19 E & 31 C & 63 B & 64 C & 71 L & 91 A & 95 B
\end{array}
$$

S First Aid

$F$ Navigate

S NBC

$W$ Weapons

F Field Techniques

$F$ Communication

W Antitank/Antiair

S Custom and law

F Drive (Operate and Maintain)

$T$ Prepare, operate, maintain howitzer and ammunition

$T$ Operate howitzer sights and alignment devices

F Preventive Maintenance

$T$ Operate Tanks

$T$ Tank Gunnery

$T$ Generators

$T \pi Y$ station and net operations

$T$ Maintain TTY electronic equipment

$T$. Operate $\pi Y$ electronic equipment

$T$ Install- $\pi r$ electronic equipment

$T$ Electrical system

$T$ Brake/steering/suspension systems

$T$ Vehicle operation and recovery

$T$ Fuel/cooling/lubricating

$T$ Forms/files management

$T$ Supervision/coordination

$T$ Correspondence

$T$ Classified Material

$T$ Clinic/ward treatment and care

$T \mathrm{Cl}$ inic/ward housekeeping

$T C l$ inic/ward management

$T$ General medical knowl edge

$T$ Responding to alarms

$T$ Conduct MP procedures

$T$ Patrol duties

$\begin{array}{llll}x^{d} & x & & \\ x & x & & \\ x & x & & \\ x & x & & \\ x & x & & \\ x & x & & \\ x & x & & \\ K 3 e & K 3 & & \\ k 3 & k 3 & & \\ & x & k 3 & K 3 \\ & x & k 3 & K 3\end{array}$

$\begin{array}{llll}K 3 & K 3 & K 3 & K 3\end{array}$

K3

K3

$x$

$x$

$x$

$x$

K3

$\begin{array}{ll}x & \\ X & \\ X & K 3\end{array}$

$x$

$x$

K3

aCommon to both the Self-propelled and Towed specialties bself-propelled only

cTowed only

dx denotes categories tested by school performance tests and job knowledge tests $e_{K} 3$ denotes categories tested by school performance tests only 


\section{Cluster Definitions \\ Batch A}

First Aid

Consists of items whose primary purpose is to indicate knowledge about how to sustain life, prevent health complications caused by trauma or environmentally induced illness, including the practice of personal hygiene. Includes all related diagnostic, transportation, and treatment items except those items normally performed in a patient care facility. Includes items related to safety and safety hazards.

Navigate

Consists of items whose primary purpose is to indicate knowledge about how to plan or execute movement between points over unknown terrain either cross-country or using road networks, or identify the location of objects. Includes all means of determining direction, distances, and locations using maps of all types, overlays, compasses, terrain, celestial objects, and field expedients.

NBC

Consists of items whose primary purpose is to indicate knowledge about performance when nuclear, biological, or chemical contaminants and threats are present, planned, detected, or expected. Includes maintenance and operation of clothing, gear, and equipment whose primary purpose is to counter, protect, or detect NBC threats. Includes NBC markers. Does not include first-aid treatment of contamination.

Weapons

Consists of items whose primary purpose is to indicate knowledge about maintenance, preparation, and firing of small arms. Small arms are defined as sized weapons, including automatic weapons, up to and including caliber .60 and shotguns. Includes ancillary sighting systems and techniques, stands and mounts, zeroing and techniques of fire. Excludes firing from aircraft and vehicles where the weapon is fired by electrical/hydraulic aiming/firing systems and sighting systems that are part of the aircraft/vehicle and not part of the weapon.

\section{Field Techniques}

Consists of items whose primary purpose is to indicate knowledge about operation orders, battlefield survival in defensive and offensive situations. Includes preparation of fighting positions, individual concealment, and cover. Includes surveillance, observation, and dismounted movement techniques in all terrain and under hostile conditions. Includes gathering combat intelligence and the practice of counterintelligence. Includes emplacement and detection of mines and boobytraps and employment of hand grenades. Includes how to prepare and maintain ambush sites and move either by vehicle or foot tactically. Includes all items having to do 
with knowledge about ambushes, and tactical movement on foot. Includes how to enter tactically a building and rooms in a building. Includes all items having to do with knowledge about entering buildings in an urban environment. Includes ways to camouflage or conceal self and motor vehicles from enemy observation in different types of areas (e.g., forests, deserts). Also covers concealing tracks and other distinguishing evidence indicating the presence of a motor vehicle.

\section{Communication}

Consists of items whose primary purpose is to indicate knowledge about the facilitation of voice transmissions over tactical wire and FM radios. It includes the use of CEOI and speech security and the maintenance and installation of communication equipment.

Antitank/Antiair Weapons

Consists of those items whose primary purpose is to indicate knowledge about how to neutralize enemy tank and air threats. Consists of both weapons and techniques and includes vehicle/aircraft recognition. Excludes weapons and techniques from aircraft and vehicles where the weapon is fired indirectly.

Customs and Laws

Consists of items whose primary purpose is to indicate knowledge about the Geneva convention, military SOP governing the treatment of enemy personnel, engagement of the enemy, the conduct of military protocol and ceremony, guard duty, and physical readiness.

Prepare, Operate, Maintain, Howitzer and Ammunition

Consists of items whose primary purpose is to indicate knowledge about tactically employing the howitzer and ammunition and maintaining both to insure reliability. Includes preparation of the howitzer position, emplacement of the howitzer and ammunition, driving, and preparing and storing ammunition at the position. Includes operator and crew maintenance, PMCS and disassembly, cleaning, and assembly of howitzer components, and inspection and recording of equipment faults on appropriate forms.

Operate Howitzer Sights and Alignment Devices

Consists of items whose primary purpose is to indicate knowledge required to orient, lay a howiter on an azimuth of fire using the howitzer sights, position aiming posts and the collimator, boresight, and engage direct fire targets from the assistant gunner's position.

\section{Preventive Maintenance}

Consists of items whose primary purpose is to indicate general knowledge about preventive maintenance activities and requirements, without regard to specific equipment. Includes completion of appropriate forms. 
Operate Tanks

Consists of items whose primary purpose is to indicate knowledge about tank driving, including items involving automotive and suspension maintenance. Includes the function, operation and maintenance of tank accessories, such as gas particulate filter system and Driver's periscope. Does not include fire control system.

Tank Gunnery

Consists of items whose primary purpose is to indicate knowledge about activities of the gunner, loader or TC in preparation for engagement, conduct of fire, and actions after engagement with the tank weapons system. Includes ammunition and maintenance of the fire control system and reaction to adverse conditions. Does not include maintenance of machineguns but includes installation and techniques of fire of these weapons.

Generators

Consists of items whose primary purpose is to indicate knowledge associated with the installation, operation, and maintenance of non-automotive generators.

TrY Station and Net Operations

Consists of items whose primary purpose is to indicate knowledge associated with operating within and controlling TTY networks. Encompasses codes, ciphers, correct message construction, handling unclassified and classified messages, station site selection and inspection, personnel assignment, the control of equipment and supplies, safety and security procedures, the preparation and maintenance of logs, records, and files, and the preparation of reports.

Mainta in TTY Electronic Equipment

Consists of items whose primary purpose is to indicate knowledge relating to the inspection of radioteletype electronic equipment as part of routine periodic maintenance procedures, the testing of new or repaired equipment; troubleshooting specific problems during oper tion to identify and repair minor defects or report major defects to maintenance personnel.

Operate TTY Electronic Equipment

Consists of items whose primary purpose is to indicate knowledge about the operation of specific radioteletype equipment including receivers, transmitters, modems, terminals, reperforators and ancillary equipment, including remote control devices, for the purpose of carrying out communication operations. 
Install TTY Electronic Equipment

Consists of items whose primary purpose is to indicate knowledge about the assembly, preparation, grounding, and installation of TTY electronic equipment, including the connection of cables, the construction or erection of expedient and non-expedient antennas, and the installation of other ancillary components prior to operation.

Electrical System

Consists of items whose primary purpose is to indicate knowledge about replacement, repair, testing and troubleshooting of vehicle electrical components. The types of vehicles range from the 1/4-ton to the 5 ton. Equipment worked on includes: starter, ignition, lights and horn.

Fuel/Cooling/Lubricating

Consists of items whose primary purpose is to indicate knowledge about vehicle fuel and cooling systems. The vehicles worked on include: 1/4-ton, 1-1/4-ton, 2-1/2-ton and the 5-ton. Includes replacing, repairing, and troubleshooting the fuel pump, thermostat, radiator and the oil filter.

Brake/Steering/Suspension Systems

Consists of items whose primary purpose is to indicate knowledge about troubleshooting, adjusting, repairing, and replacing components of the braking, steering, or suspension system of wheeled vehicles up through 5 ton. Includes repair/replacement of brake master cylinder, brake shoes, hand brake, torque rods, shock absorbers, and axle shafts.

Vehicle Oderation and Recovery

Consists of items whose primary purpose is to indicate knowledge about the operation and maintenance of organic vehicles including wreckers and shop vans and the operation and maintenance of general and specific tools and equipment assigned to those vehicles. Includes wheeled vehicle recovery and emergency repairs performed in conjunction with field recovery.

Drive (Operate and Maintain)

Consists of items whose primary purpose is the indicate knowledge required to operate vehicles and trailers in usual and unusual conditions, on and off road, alone and in convoy. Items also focus on the proper procedures (e.g., loading, driving) to follow when transporting passengers, weapons, ammunitions, and hazardous cargo. It also covers understanding road signs and hand signals. Includes supervision of loading/unloading and cargo security. Includes reaction to emergency driving conditions. Includes operator maintenance of non-MOS specific wheel or track vehicles, or both. Includes completion of appropriate forms. 
Forms/Files Management

Consists of items whose primary purpose is to indicate knowledge about how to prepare and maintain files, forms, publications and correspondence. Includes establishing and updating functional files, reviewing personnel forms, preparing file plans, and requisitioning publications.

Supervision/Coordination

Consists of items whose primary purpose is to indicate knowledge about the management of personnel, supplies and office equipment. Includes briefing personnel, recommending awards and discharges, writing reports, counseling personnel and selecting details.

Correspondence

Consists of items whose primary purpose is to indicate knowledge about preparing and managing military forms, letters, and other official correspondence. Includes typing memos, letters, and disposition forms, dispatching distribution and assembling correspondence. Also includes answering inquiries and carrying out normal office routine.

Classified Material

Consists of items whose primary purpose is to indicate knowledge about receipt, control, and dispatch of classified documents. Includes safeguarding fOUO material, maintaining an office security plan, inventorying classified documents, and controlling sensitive forms.

Clinic/Ward Treatment and Care

Consists of items whose primary purpose is to indicate knowledge about routine and emergency services administered to patients and casualties in a hospital or clinic in either garrison or field settings. It includes day-to-day care, such as reading vital signs, conducting tests or measurements, and administering injections and other medications requested by physician; assisting patients in regaining strength and movement, and in personal care; and responding to real or potential emergencies, such as seizures, poison, tracheal suction.

Clinic/Ward Housekeeping

Consists of items whose primary purpose is to indicate knowledge about how to maintain safe and sanitary conditions in clinic or ward. Includes cleaning of equipment, maintaining supplies, checking safety equipment, temperature, and ventilation.

Clinic/Ward Management

Consists of items whose primary purpose is to indicate knowledge about how to assure patient flow through facility, and the maintenance and processing of patient and clinic records and forms. Includes emergency evacuation of patients. Patient contact involves admitting and discharge paperwork, escorting patients, or briefing them on facility rules and services. 
General Medical Knowledge

Consists of items whose primary purpose is to indicate general medical knowledge. Examples of topics are: identification and function of the muscular, digestive, auditory, and respiratory systems, origins of various kinds of infections and illnesses, types of burns, and the function of the body's defense system.

Responding to Alarms

Consists of items whose primary purpose is to indicate knowledge about how to report to the scene of a real or impending crisis and act to control or reduce danger. Includes bomb threats, traffic accidents, domestic

disturbances or other alarms.

\section{Patrol Duties}

Consists of items whose primary purpose is to indicate knowledge associated with day-to-day police activities, including traffic control, investigations, searching suspects and buildings, and completing incident reports. Includes procedures on how to control an area in different situations. Situations include: route reconnaissance, circulation control points, establishing and operating a roadblock.

\section{Conduct MP Procedures}

Consists of items whose primary purpose is to indicate-knowledge about the correct procedures in various MP situations: apprehending suspects, conducting building, vehicle, and person searches, collecting and processing evidence, transporting offenders, reading the Miranda Rights (Article 31), and patrolling. Also includes preparing and filing the MP reports. Includes the guidelines pertinent to how an MP should conduct himself/herself, or to determine proper procedure in handling various MP situations. These guidelines pertain to: force in apprehension and arrest and when to use it, methods and rules of searches, interviewing offenders/witnesses/complaintants, testifying in court, and duties and proper conduct of an MP. 
$S$ First Aid

F Mavigate

5 MBC

i. Heapons

f Field Techniques

F Comunication

H Antitank/Antiair

5 Custom and law

F Orive (Operate and Maintain)

$F$ Generators

F Preventive maintenance

T Bridging/River crossing

$T$ Field fortiffcations and obstacles

$T$ Unit personnel management and superviston

$T$ Redeye

$T$ Stinger

$T$ Electronics

$T$ TADCS

$T$ TOW components and TOW test components

T Training equipment and simulators (TOW)

$T$ Dragon components

$T$ Dragon test sets and simulators

$T$ Construction tools and materials

$T$ Construction

T Rigging

$T$ Math

T Chemical/8iological/Radiological operations

$T$ Decontamination operations and equipment

$T$ Amonition

$T$ Denol tition

$T$ Amunition markings/characteristics

$T$ Storage/ transportation symbols and signs

$T$ Amanition adainistration

$T$ Hel icopter ma intenaince

$T$ Aircraft mafntenance admintstration

$T$ Aircraft refueling

$T$ Landing/take-off stgnals

T Alrcraft maintenance tools/equipment

$T$ Petroleum, ofls, Iubricants (POL) site construction

$T$ POL site operation

$T$ POL storage and administration

$T$ POL equipment maintenance

$T$ POL issue/turn-in/transfer

$T$ Transport POL products

$T$ Personal/Organizational clothing/ Individual equfpment

T Supply adininistration

$T$ Supply storage

$T$ Property Book accounting

T Unit supply management

$T$ Untt armory

$T$ Non-meat food preparation

$T$ Meat preparation

$T$ Food service

$T$ Food service equipment/administration

$T$ General Beverage/Food Preparation

$\begin{array}{llllllllll}12 B & 165 & 27 E & 518 & 54 E & 55 B & 67 N & 76 \mathrm{~W} & 76 Y & 94 B \\ K 3 & K 3 & K 3 & K 3 & K 3 & K 3 & K 3 & K 3 & K 3 & K 3 \\ K 3 & K 3 & K 3 & K 3 & K 3 & K 3 & K 3 & K 3 & K 3 & K 3 \\ K 3 & K 3 & K 3 & K 3 & K 3 & K 3 & K 3 & & K 3 & K 3 \\ K 3 & K 3 & K 3 & K 3 & K 3 & K 3 & K 3 & K 3 & K 3 & K 3 \\ K 3 & K 3 & K 3 & K 3 & K 3 & K 3 & K 3 & K 3 & K 3 & K 3 \\ K 3 & K 3 & K 3 & K 3 & K 3 & K 3 & K 3 & K 3 & K 3 & K 3 \\ K 3 & K 3 & K 3 & K 3 & K 3 & K 3 & K 3 & K 3 & K 3 & \\ K 3 & K 3 & K 3 & K 3 & K 3 & K 3 & K 3 & K 3 & K 3 & K 3 \\ K 3 & K 3 & K 3 & K 3 & K 3 & K 3 & & K 3 & K 3 & \\ K 3 & K 3 & K 3 & K 3 & K 3 \\ K 3 & K 3 & K 3 & K 3 & K 3 & K 3 & & & K 3 & K 3\end{array}$

K3

K3

K3

K3
K3

K3

$\times 3$

K3

K3

$K$
K3

K3

$\times 3$

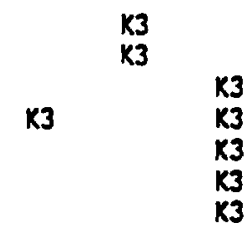

lbatch $Z$ MOS did not have job performance tests developed, only school performance tests (K3). 


\section{Cluster Definitions \\ Batch Z}

First Aid

Consists of items whose primary purpose is to indicate knowledge about how to sustain life, prevent health complications caused by trauma or environmentally induced illness, including the practice of personal hygiene. Includes all related diagnostic, transportation, and treatment items except those items normally performed in a patient care facility. Includes items related to safety and safety hazards.

Navigate

Consists of items whose primary purpose is to indicate knowledge about how to plan or execute movement between points over unknown terrain either cross-country or using road networks, or identify the location of objects. Includes all means of determining direction, distances, and locations using maps of all types, overlays, compasses, terrain, celestial objects, and field expedients.

NBC

Consists of items whose primary purpose is to indicate knowledge about performance when nuclear, biological, or chemical contaminants and threats are present, planned, detected, or expected. Includes maintenance and operation of clothing, gear, and equipment whose primary purpose is to counter, protect, or detect NBC threats. Includes NBC markers. Does not include first-aid treatment of contamination.

Weapons

Consists of items whose primary purpose is to indicate knowledge about maintenance, preparation, and firing of small arms. Small arms are defined as sized weapons, including automatic weapons, up to and including caliber .60 and shotguns. Includes ancillary sighting systems and techniques, stands and mounts, zeroing and techniques of fire. Excludes firing from aircraft and vehicles where the weapon is fired by electrical/hydraulic aiming/firing systems and sighting systems that are part of the aircraft/vehicle and not part of the weapon.

Field Techniques

Consists of items whose primary purpose is to indicate knowledge about operation orders, battlefield survival in defensive and offensive situations. Includes preparation of fighting positions, individual concealment, and cover. Includes surveillance, observation, and dismounted movement techniques in all terrain and under hostile conditions. Includes gathering combat intelligence and the practice of counterintelligence. Includes emplacement and detection of mines and boobytraps and employment of hand grenades. Includes how to prepare and maintain ambush sites and 
move either by vehicle or foot tactically. Includes all items having to do with knowledge about ambushes, and tactical movement on foot. Includes ways to camouflage or conceal self and motor vehicles from enemy observation in different types of areas (e.g., forests, deserts). Also covers concealing tracks and other distinguishing evidence indicating the presence of a motor vehicle.

Communication

Consists of items whose primary purpose is to indicate knowledge about the facilitation of voice transmissions over tactical wire and FM radios. It includes the use of CEOI and speech security and the maintenance and installation of communication equipment.

Antitank/Antiair Weapons

Consists of those items whose primary purpose is to indicate knowledge about how to neutralize enemy tank and air threats. Consists of both weapons and techniques and includes vehicle/aircraft recognition. Excludes weapons and techniques from aircraft and vehicles where the weapon is fired indirectly.

Customs and Laws

Consists of items whose primary purpose is to indicate knowledge about the Geneva convention, military SOP governing the treatment of enemy personnel, engagement of the enemy, the conduct of military protocol and ceremony, guard duty, and physical readiness.

Preventive Maintenance

Consists of items whose primary purpose is to indicate general knowledge about preventive maintenance activities and requirements, without regard to specific equipment. Includes completion of appropriate forms.

Drive (Operate and Maintain)

Consists of items whose primary purpose is the indicate knowledge required to operate vehicles and trallers in usual and unusual conditions, on and off road, alone and in convoy. Items al so focus on the proper procedures (e.g., loading, driving) to follow when transporting passengers, weapons, ammunitions, and hazardous cargo. It also covers understanding road signs and hand signals. Includes supervision of loading/unloading and cargo security. Includes reaction to emergency driving conditions. Includes operator maintenance of non-MOS specific wheel or track vehicles, or both. Includes completion of appropriate forms.

Generators

Consists of items whose primary purpose is to indicate knowledge associated with the installation, operation, and maintenance of non-automotive generators. 
Bridging/River Crossing

Consists of items whose primary purpose is to indicate knowledge associated with river crossing (transporting of vehicles and personnel over bodies of water, such as use of a pneumatic assault boat), or the construction of bridges/structures used to facilitate the crossing of bodies of water by personnel or vehicles (i.e., float bridge, anchorage support system, transom, Stringer).

\section{Field Fortifications and Obstacles}

Consists of items whose primary purpose is to indicate knowledge associated with the construction, removal or breachment of fortifications (i.e., basic, individual, hasty, and defensive fighting positions, log structures) and obstacles (i.e., abatis, concertina/barbed wire, hedgehog).

Unit Personnel Management and Supervision

Consists of items whose primary purpose is to indicate knowledge associated with the supervision or management of unit personnel on a day-to-day basis, including any administrative paperwork associated with the accountability of unit materials and equipment.

Redeye

Consists of items whose primary purpose is to indicate knowledge about the maintenance, use, and destruction of the Redeye weapon. Includes scanning patterns, engaging targets, misfires, weapons control status, and techniques for destroying the Redeye weapon.

Stinger

Consists of items whose primary purpose is to indicate knowledge about the maintenance, use, and destruction of the Stinger weapon. Includes scanning patterns, engaging targets, misfires, transporting, and destroying the Stinger weapon.

Electronics

Consists of items whose primary purpose is to indicate knowledge about electrical circuits and soldering.

TADDS

Consists of items whose primary purpose is to indicate knowledge about the maintenance and use of the Target Alert Data Display Set (TADDS).

TOW Components and TOW Test Components

Consists of items whose primary purpose is to indicate knowledge about the major components of the TOW and the testing of these components. Does not include training equipment or simulators. The major components are: 1) the tripod; 2) traversing unit; 3) optical sight;4) missile guidance set 
and battery assembly; 5) contact support set. Included are the self-tests and testing equipment for these components as well as 422 oscilloscope, 15 KW generator, power supply assembly, effectiveness range, and TOW 2.

Training Equipment and Simulators (TOW)

Consists of items whose primary purpose is to indicate knowledge about the use and maintenance of TOW training equipment and simulators. Includes missile simulation round, target source and power supply modulator, and instructor console.

Dragon Components

Consists of items whose primary purpose is to indicate knowledge about major Dragon components. Includes infrared tracker, Dragon night sight, Dragon round, Dragon M175 mount, Dragon Control Signals Comparator Board, and Vehicle Power Conditioner. Does not include test sets or training equipment.

Dragon Test Sets and Simulators

Consists of items whose primary purpose is to indicate knowledge about the use and maintenance of test sets and simulators. Includes tracker test set, test adapter MX-10078/G, Optical Alignment Collimator, Launcher Effects Trainer (LET), and monitoring sets.

Construction Tools and Materials

Consists of items whose primary purpose is to indicate knowledge about the selection, use, specifications, and maintenance of tools and construction materials. Included are measuring tools and all tools used for construction and materials such as lumber and nails. Not included are materials and tools used for field fortifications or obstacles. Al so excluded are tasks related to actual construction procedures (e.g., building a wall).

Construction

Consists of items whose primary purpose is to indicate knowledge about construction procedures. Includes planning for construction and construction techniques (e.g., walls, floors, stairways). Masonry is also included (i.e., screeding, cement, construction using brick/cinderblock).

Rigging

Consists of items whose primary purpose is to indicate knowledge about the use of rope or string for tying knots or lashing materials together. Includes hitches and tackle blocks. Does not include knots made with materials other than rope or string (i.e., wire used in demolition). 
Math

Consists of items whose primary purpose is to indicate knowledge about the application of math for determining needed materials or converting fractions and decimals. Included are procedures requiring multiplication, addition, division, and subtraction.

Chemical/Biological/Radiological Operations

Consists of items whose primary purpose is to indicate knowledge about identifying, measuring, reporting, and reacting to Chemical, Biological, or Radiological attack. Includes measurement equipment maintenance and operation. Does not include protective or decontamination equipment.

Decontamination Operations and Equipment

Consists of items whose primary purpose is to indicate knowledge about decontaminating NBC areas. Includes decontamination and protective equipment maintenance and operation.

Ammunition

Consists of items whose primary purpose is to indicate knowledge about ammunition: storing and packing ammunition (i.e., DOOIC and other markings on packs, rewarehousing of ammunition, determining rounds stored on pallets), loading and shipping ammunition to include refueling in ammunition storage area, explosive trains, determining issuability of ammunition, and sling-out operations signals, maintaining ammunition (i.e., repair/damage to stored ammunition); detroying and disposing ammunition to include safety procedures (i.e., safe distances), and identifying and using storage tools and equipment (i.e., RTFL). Does not include identifying ammunition by type, markings or characteristics.

Demolition

Consists of items whose primary purpose is to indicate knowledge associated with the engineering, activation or deactivation, and use of demolitions (i.e., M700, blasting cap, time-blasting fuse, M51 test set, M5A1 demolition block, MBAl demolition charge, dual-firing systems). Includes warnings and safety practices employed before detonation.

Ammunition Markings/Characteristics

Consists of items whose primary purpose is to indicate knowledge about the identification of conventional, special, and explosive ammunition by type, physical features, lot numbers, weight zone, and color codes: (1) Small arms (i.e., Caliber .22, caliber .50, $7.62 \mathrm{~mm}$ ); (2) Artillery (i.e.. anti-tank, high-explosive, howitzer, practice, chemical, semi-fixed); Mines (i.e., anti-tank, self-destructing, M19/nonmetallic, M14 antipersonnel, M16A1 antipersonnel, M18A1 Claymore); (4) Mortars (i.e., $60 \mathrm{~mm}$ HE, 81MM illuminating, 4.2 inch HE); (5) Fuzes (i.e., point detonating, combination, pressure, delay-detonating, proximity/T); (6) Anti-armor (i.e., APFSOS-T, HEAT-T); (7) Grenades (i.e., M18, MK3A2 
offensive, AN-M8, HC smoke, M15 WP smoke, incendiary); (8) Rockets (i.e., $66 \mathrm{~mm}$ incendiary, M74, LSFFAR); (9) Illumination/flares; and (10) simulators (i.e., M80). Included are items pertaining to warning signs and markers involved in field techiques (i.e., minefield).

Storage/Transportation Symbols and Signs

Consists of items whose primary purpose is to indicate knowledge about the recognition and identification of signs and symbols used for storing and transporting hazardous agents (i.e., fire, chemical, nerve and mustard, detonation).

Ammunition Administration

Consists of items whose primary purpose is to indicate knowledge about the paperwork associated with requests for issue and turn-in of ammunition. Coverage includes correctly accomplishing the following forms: (1) DA Form 581; (2) DA Form 3151-R; (3) DA Form 2000-3; and (4) DA Form 3020-R.

Helicopter Maintenance

Consists of items whose primary purpose is to indicate knowledge about the inspection and-maintenance of the UH-1 hel icopter. Includes a) General; b) Inspections/Quality Assurance; c) Airframe/Landing Gear; d) Power Plant Systems; e) Transmission/Rotor Systems; f) Flight Control Systems; g) Utility/Hydraulic Systems; and h) Instrument/Electrical Systems.

Aircraft Maintenance Administration

Consists of items whose primary purpose is to indicate knowledge about the proper documentation of aircraft maintenance. Includes all DA forms used for aircraft maintenance, PMCS schedules and checklists, and symbols used for documentation.

Aircraft Refueling

Consists of items whose primary purpose is to indicate knowledge about the safe refueling of aircraft, including grounding procedures.

\section{Landing/Takeoff Signals}

Consists of items whose primary purpose is to indicate knowledge about the use of hand/arm signals used by ground crew to signal pilot for landing and takeoff of aircraft.

Aircraft Maintenance Tools/Equipment

Consists of items whose primary purpose is to indicate knowledge about the selection, use, and maintenance of tools and equipment for the inspection and maintenance of aircraft. 
Petroleum, Oils, Lubricants (POL) Site Construction

Consists of items whose primary purpose is to indicate knowledge about the selection and construction of POL sites. Coverage includes: (1) Determine requirements for POL hoseline/pipeline systems; (2) Recommend sites for pump stations; (3) Ground POL pumps/filters/separators; and (4) Identify POL products used in pipelines. Also included are implacing/repairing collapsible tanks.

POL Site Operation

Consists of items whose primary purpose is to indicate knowledge about the procedures and operations of a $\mathrm{POL}$ site. Items include coverage of testing/checking for water/sediment/sludge/contamination in POL products (including conducting the API gravity test), quality control measures, operation of the tank and pump unit, and a thorough knowledge of the function of the various elements of a POL pipeline. Also included are monitoring the flow of POL products (DA Form 4193) and reporting pipeline leaks (OA Form 10-242), filling POL containers, and removal of oil spills.

POL Storage and Administration

Consists of items whose primary purpose is to indicate knowledge about the storage of POL products and administrative paperwork associated with requests and receipts of POL products. Items include those pertaining to the identification of stored containers of POL products (i.e., type, supply class, markings, volume), cleaning/preparation of POL storage containers, stacking POL containers in storage area, and maintenance of stored POL products. Coverage also includes gaging storage/rail tanks, inventory of POL products (DA Form 2000-3), determining conversion factor for fuel, and familiarity with the storage locator system.

POL Equipment Maintenance

Consists of items whose primary purpose is to indicate knowledge about the maintenance and repair of POL equipment. Coverage includes repair of coupled/welded pipeline (e.g., leaks, holes), completion of appropriate paperwork (DA Form 2404), and monitoring the pressure at the POL stations. Also included is knowledge of items related to pipeline scraper.

POL Issue/Turn-In/Transfer

Consists of items whose primary purpose is to indicate knowledge about the issue/turn-in/transfer of POL products. Included are coverage of items pertaining to the administrative paperwork of issuing POL products (DA Form 3643 and DA Form 3644). Also included is knowledge about the FARE system and usage of aviation fuels, and refueling/defueling operations of vehicles. Not included here are refueling/defueling operations of aircraft and hand signals used in landing/take-off of aircraft.

Transport POL Products

Consists of items whose primary purpose is to indicate knowledge about the transportation of POL products by rail tank car/truck. Coverage includes a 
knowledge of the features of a tank car/truck, loading/unloading operations of POL products, and familiarity with FSSP.

Personal/Organizational Clothing/Individual Equipment

Consists of items whose primary purpose is to indicate knowledge about activities that are associated with the completion and routing of personal clothing and organizational clothing and individual equipment forms: (1) Laundry (i.e., payroll deduction laundry service, DA Form 2886 , DA form 3136, DA Form 1974); (2) Clothing (i.e.., Personal Clothing Request issue or replace personal clothing, misfit clothing or footwear); and (3)

Clothing/Equipment (i.e., OCIE, DA Forms 3645 and $3645-1$ ).

Supply Administration

Consists of items whose primary purpose is to indicate knowledge associated with the day-to-day paperwork involving supplies. Topic coverage includes general administrative knowledge (i.e., Julian date calendar, Supply Support Activity, Class I, V, and MRE supplies, expendable supplies, excess items, CTA, DA PAM 310-1), knowledge involving request/requisitions (i.e., urgency), knowledge pertaining to receipt of supplies (i.e., DODAAC, Delegation of Authority - Receipt for Supplies), and knowledge involving the issue/turn-in/transfer of supplies ( $i . e ., D A$ Forms 2765 and $2765-1$, DA Form 3161, hand receipt, change document, shortage annex, DIC, status cards).

Supply Storage

Consists of items whose primary purpose is to indicate knowledge about the storage of supplies. Includes separating stored supplies by class and type. Does not include ammunition.

Property Book Accounting

Consists of items whose primary purpose is to indicate knowledge related to Property Book Accounting. Includes automated procedures (i.e., microfiche) as well as manual procedures (i.e., DA Form 2064 - Document Register for Supply Actions).

Unit Supply Management

Consists of items whose primary purpose is to indicate knowledge related to the management of supplies for a unit (i.e., AMDF, unit DODAAC, Subhand Receipt Holder).

Unit Armory

Consists of items whose primary purpose is to indicate knowledge pertaining to the control of the unit armory. Topic coverage includes: (1) Triple Barrier System; (2) Secondary arms room lock; (3) Weapons Storage/Key Control Register; (4) Monthly Weapon and Ammunition Inventory Register; and (5) DA From 3749. Al so covered are procedures employed for privately owned weapons. 
Non-Meat Food Preparation

Consists of items whose primary purpose is to indicate knowledge about the correct procedures involved in the preparation and use of non-meat food. Coverage includes the following: (1) Sauces/gravy/stuffing/dressing (bread and salad); (2) Beverages (dry and fluid); (3) Breakfast foods (i.e., omelet, fruit fritters, pancakes, waffles, hot cereal), (4) Short order/box lunch (i.e., French fries, sandwiches); (5) Soup; (6) Appetizer/salad/ relish; (7) Vegetable; (8) Non-pastry dessert (i.e., pudding, soft-serve ice cream); (9) Baked goods (i.e., bread, pie crust, cake, muffins).

Meat Preparation

Consists of items whose primary purpose is to indicate knowledge about the preparation and use of meat products (including entrees and pasta) such as beef, pork, poultry, and seafood.

Food Service

Consists of items whose primary purpose is to indicate knowledge about food service. Coverage includes: (I) Serving (i.e., garnishes, serve liquid/ semi-liquid foods, stack sandwiches, determine serving portions, arrange serving table, maintain steam table, arrange and prepare electric cold food counter); and (2) Field food service/site preparation (i.e., use of insulated food containers, assemble immersion heater, set up field kitchen and field latrine, wash dishes in field kitchen, pitch tent and protect from rain).

Food Service Equipment/Administration

Consists of items whose primary purpose is to indicate knowledge about the operation and maintenance of food service equipment. Equipment to be included: (1) M2 burner unit; (2) Stack oven; (3) Electric deep-fat fryer; (4) coffee urn; (5) Immersion heater; (6) Gasol ine lantern generator; (7) Refrigerator; (8) $\mathrm{Knife}$; and (9) M59 range. Covers topics that involve identification of cooking utensils, and knowledge of safety practices and procedures when operating/maintaining food service equipment.

General Beverage/Food Preparation

Consists of items whose primary purpose is to indicate knowledge about the general preparation of beverages and foods. Coverage includes:

(1) increase/decrease recipes; (2) measure ingredients; (3) season foods;

(4) preserve fresh fruits/vegetables; (5) peel/cut/dice/slice, and core foods; (6) trim, wash, and drain foods; (7) prepare leftovers; and (8) ready equipment for use. Also includes a general knowledge of the definitions of cooking/baking terms. 
Appendix B

Functional and Cognitive Categories with Test Items 
Appendix B

Functional and Cognitive Categories with Test Items 


\begin{tabular}{|c|c|c|c|c|c|c|c|}
\hline & & $\begin{array}{c}K 1 \\
x_{1}=119\end{array}$ & $\begin{array}{c}K 2 \\
K_{2}=25\end{array}$ & $\begin{array}{l}k 3 \\
K_{3}=4\end{array}$ & $\begin{array}{c}K_{4} \\
K_{4}=2\end{array}$ & $\begin{array}{l}\text { Total N } \\
\text { of Items }\end{array}$ & $\%$ \\
\hline $\mathrm{s}$ & First Aid & $\begin{array}{l}22,24,26,27,32,113, \\
114,115, \underset{(30}{(N=9)}\end{array}$ & $\begin{array}{c}23 \\
(N=1)\end{array}$ & & & 10 & .07 \\
\hline $\mathrm{F}$ & Navigate & $\begin{array}{c}65,66,67,68,69,70, \\
72,73,74,75,76,77, \\
78,122 \quad(N=14)\end{array}$ & & $\begin{array}{c}71 \\
(N=1)\end{array}$ & & 15 & .10 \\
\hline s & NBC & $19,20,21$ & $\begin{array}{r}18,25 \\
(N=2)\end{array}$ & & & 5 & .03 \\
\hline$H$ & Heapons & $\begin{array}{c}1,2,3,5,6,8,13,14, \\
15,38,43,94,95,96 \\
(N=14)\end{array}$ & $\begin{array}{l}4,7, i^{11,12} \\
16=6)\end{array}$ & $\begin{array}{c}48 \\
(N=1)\end{array}$ & & 21 & .14 \\
\hline $\mathrm{F}$ & $\begin{array}{l}\text { Field } \\
\text { Techniques }\end{array}$ & $\begin{array}{l}28,29,30,33,34,35, \\
36,37,39,40,41,42, \\
44,45,46,49,50,51, \\
54,55,56,59,60,64, \\
86,87,88,89,90,91, \\
92,93,100,103,104, \\
105,127,128,129,131, \\
132,135,136,137,141 \\
(N=45)\end{array}$ & $\begin{array}{l}52,101,102, \\
134\end{array}$ & & $\begin{array}{l}53,47 \\
(N=2)\end{array}$ & 51 & .34 \\
\hline$F$ & Communication & $79,80,81,82,83,84$ & $\begin{array}{l}85 \\
(N=1)\end{array}$ & $\begin{array}{c}133 \\
(N=1)\end{array}$ & & 8 & .05 \\
\hline 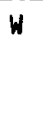 & $\begin{array}{l}\text { Antitank/ } \\
\text { Antiair } \\
\text { Weapons }\end{array}$ & $\begin{array}{c}57,58,63,98,116,123, \\
124,125, \underset{226}{(N=9)}\end{array}$ & $\begin{array}{c}9,10,117 \\
(N=3)\end{array}$ & $\begin{array}{c}118 \\
(N=1)\end{array}$ & & 13 & .09 \\
\hline 5 & Customs \& Laws & $\begin{array}{c}31,61,62,99,106,107, \\
109,119,120,121,138, \\
139,140,142,143,144, \\
146,147, \\
(N-18)\end{array}$ & $\begin{array}{c}108,110,111, \\
112,145,148, \\
149,150 \\
(N=8)\end{array}$ & & & 26 & .17. \\
\hline $\mathrm{F}$ & Drive & $(N=1)$ & & & & 1 & .006 \\
\hline
\end{tabular}

118

F - Field Skills

W - Heapons Operation and Maintenance

S - Survival

$T$ - Technical knowledge as defined on Page 6

KI - Recognition of objects and words, recall of facts and principles

K2 - Recall of procedures and steps of procedures

K3 - Application of principles

K4 - Inferring from a general principle as defined on page 9 


\begin{tabular}{|c|c|c|c|c|c|c|c|}
\hline & & $\begin{array}{c}k_{1} \\
k_{1}=113\end{array}$ & $\begin{array}{c}K_{2} \\
K_{2}=33\end{array}$ & $\begin{array}{c}K_{3} \\
K_{3}=5\end{array}$ & $\begin{array}{c}K 4 \\
K_{4}=5\end{array}$ & $\begin{array}{l}\text { Total N } \\
\text { of Items }\end{array}$ & 8 \\
\hline s & First Aid & $3,4, \underset{(N=4)}{67}, 68$ & $\begin{array}{r}40,41 \\
(N=2)\end{array}$ & & & 6 & .04 \\
\hline$F$ & Navigate & $31, \begin{array}{c}32,33,35 \\
(N=4)\end{array}$ & & $\begin{array}{l}34,36 \\
(N=2)\end{array}$ & & 6 & .04 \\
\hline 5 & NBC & $69, \begin{array}{c}71,72,73 \\
(N=4)\end{array}$ & $\begin{array}{r}17, \quad 70 \\
(\dot{N}=2)\end{array}$ & & $\begin{array}{c}16 \\
(N=1)\end{array}$ & 7 & .04 \\
\hline$w$ & Weapons & $\begin{array}{c}27,30,83,84,85,87, \\
(N=7)\end{array}$ & $\begin{array}{l}5,20,82,86, \\
93,94 \\
(N=6)\end{array}$ & $\begin{array}{c}29 \\
(N=1)\end{array}$ & & 14 & .09 \\
\hline $\mathbf{F}$ & $\begin{array}{l}\text { Field } \\
\text { Techniques }\end{array}$ & $\begin{array}{c}18,22,25,89,90,101 \\
(N=6)\end{array}$ & $\begin{array}{c}28 \\
(N=1)\end{array}$ & & $\begin{array}{c}21,26,37 \\
(N=3)\end{array}$ & 10 & .06 \\
\hline $\mathbf{F}$ & Communication & $19,38, \underset{(M-6)}{39,44}, 45,92$ & & & & 6 & .04 \\
\hline$W$ & $\begin{array}{l}\text { Antitank/ } \\
\text { Antiair } \\
\text { Weapons }\end{array}$ & $\begin{array}{c}74 \\
(N-1)\end{array}$ & & & & 1 & .005 \\
\hline$s$ & Customs \& Laws & $53,55, \underset{(N=6)}{58,} 50,61$ & $\begin{array}{c}54 \\
(N=1)\end{array}$ & & $\begin{array}{c}66 \\
(N=1)\end{array}$ & 8 & .05 \\
\hline $\mathbf{F}$ & Drive & $\begin{array}{r}23,62 \\
(\dot{N}=2)\end{array}$ & $\begin{array}{r}24,63 \\
(\dot{N}=2)\end{array}$ & & & 4 & .03 \\
\hline$T$ & $\begin{array}{l}\text { Operate } \\
\text { Howitzer S1 ghts } \\
\text { and Ai gignment } \\
\text { Devices }\end{array}$ & $\begin{array}{l}1,2,9,11,12,13,95, \\
97,99,100,102,104, \\
105,107,108,152,153 \\
(N=13))\end{array}$ & $\begin{array}{c}6,8,51,91 \\
103,106,109 \\
(N=7)\end{array}$ & $\begin{array}{c}7 \\
(N=1)\end{array}$ & & 25 & .16 \\
\hline$T$ & $\begin{array}{l}\text { Prepare, } \\
\text { Operate, } \\
\text { Maintain } \\
\text { Howftzer : } \\
\text { Ammunition }\end{array}$ & $\begin{array}{l}10,14,42,43,46,47, \\
48,50,52,56,57,64, \\
65,75,76,77,79,80, \\
81,96,98,110,111, \\
112,113,114,116,117, \\
118,121,122,123,124, \\
125,126,127,129,131, \\
133,134,135,136,137, \\
138,139,140,141,144, \\
145,146,148,150,151, \\
154,155,156 \\
(N=56)\end{array}$ & $\begin{array}{l}15,49,78 \\
115,119,120, \\
128,130,142, \\
143,147,149\end{array}$ & $(N-1)$ & & 69 & .44 \\
\hline
\end{tabular}

138-T 


\begin{tabular}{|c|c|c|c|c|c|c|c|}
\hline & & $\begin{array}{c}K 1 \\
K_{1}=96\end{array}$ & $\begin{array}{c}K 2 \\
K_{2}=31\end{array}$ & $\begin{array}{c}k 3 \\
k_{3}=4\end{array}$ & $\begin{array}{c}K_{4} \\
K_{4}=5\end{array}$ & $\begin{array}{l}\text { Total N } \\
\text { of It ems }\end{array}$ & $x$ \\
\hline$S$ & First Aid & 3, ${ }_{(N=4)}^{67}, 68$ & $\begin{aligned} & 40, 41 \\
&(N=2)\end{aligned}$ & & & 6 & .04 \\
\hline $\mathbf{F}$ & Navigate & $31, \begin{array}{c}32,33,35 \\
(N=4)\end{array}$ & & $\begin{array}{l}34,36 \\
(N=2)^{36}\end{array}$ & & 6 & .04 \\
\hline $\mathbf{S}$ & MBC & 69, $\underset{(1,12,73)}{ }$ & $\begin{array}{r}17,70 \\
(N=2)\end{array}$ & & $\begin{array}{c}16 \\
(N=1)\end{array}$ & 7 & .05 \\
\hline $\boldsymbol{W}$ & Weapons & $\begin{array}{c}27,30,83,84,85,87, \\
(N=7)\end{array}$ & $\begin{array}{c}5,20,82,86, \\
93,94(N=6)\end{array}$ & $\begin{array}{c}29 \\
(N=1)\end{array}$ & & 14 & .10 \\
\hline $\mathbf{F}$ & $\begin{array}{l}\text { Field } \\
\text { Techniques }\end{array}$ & $\begin{array}{c}18,22,25,89,90,101 \\
(N=6)\end{array}$ & $\begin{array}{l}28 \\
(N=1)\end{array}$ & & $\begin{array}{c}21,26,37 \\
(N=3)\end{array}$ & 10 & .07 \\
\hline $\mathbf{F}$ & Communt cation & $19,38, \begin{array}{c}39,44,45,92 \\
(N=6)\end{array}$ & & & & 6 & .04 \\
\hline$w$ & $\begin{array}{l}\text { Antitank/ } \\
\text { Antiair } \\
\text { Weapons }\end{array}$ & $\begin{array}{c}74 \\
(N=1)\end{array}$ & & & & 1 & .005 \\
\hline $\mathbf{F}$ & Customs \& Laws & $53,55,58, \underset{(N=6)}{59}, 60,61$ & $\begin{array}{l}54 \\
(N=1)\end{array}$ & & $\begin{array}{c}66 \\
(N=1)\end{array}$ & 8 & .06 \\
\hline $\boldsymbol{F}$ & Drive & $\begin{array}{r}23,62 \\
(M=2)\end{array}$ & $\begin{array}{r}24,63 \\
(N=2)\end{array}$ & & & 4 & .03 \\
\hline$T$ & $\begin{array}{l}\text { Operate } \\
\text { Howt tzer sights } \\
\text { and Al i gnment } \\
\text { Devices }\end{array}$ & $\begin{array}{l}1,2,9,11,12,13 ; 95, \\
97,99,100,102,121, \\
130 . \\
(N=13)\end{array}$ & $\begin{array}{c}6,8,51,91, \\
(N=4)\end{array}$ & $\begin{array}{c}7 \\
(N=1)\end{array}$ & . & 18 & .13 \\
\hline$T$ & $\begin{array}{l}\text { Prepare, } \\
\text { Operate, } \\
\text { Maintain } \\
\text { Howitzer \& } \\
\text { Ammunition }\end{array}$ & $\begin{array}{l}10,14,42,43,46,47, \\
48,50,52,56,57,64, \\
65,75,76,77,79,80, \\
81,96,98,103,106, \\
107,109,111,114,115, \\
116,118,119,122,123, \\
124,125,127,129,131, \\
132,133,134 ; 135,136, \\
(N=43)\end{array}$ & $\begin{array}{l}15,49,78, \\
104,105,108, \\
110,112,113, \\
117,120,126, \\
128 \\
(N=13)\end{array}$ & & & 56 & .41 \\
\hline
\end{tabular}

13B-SP 


\begin{tabular}{|c|c|c|c|c|c|c|c|}
\hline & & $\begin{array}{c}k 1 \\
x_{1}=115\end{array}$ & $\begin{array}{c}k 2 \\
x_{2}=38\end{array}$ & $\begin{array}{c}k 3 \\
K_{3}=7\end{array}$ & $K_{4}^{K=2}$ & $\begin{array}{l}\text { Total N } \\
\text { of Items }\end{array}$ & 8 \\
\hline$S$ & First Aid & $\begin{array}{c}120,132,135,139,140, \\
(N=6)\end{array}$ & $\begin{array}{l}117 \\
(N=1)\end{array}$ & & & 7 & .04 \\
\hline$F$ & Navigate & $\begin{array}{l}92,93,94,95,96,97, \\
99,100,101(N=9) \\
(N=9)\end{array}$ & & $\begin{array}{c}98 \\
(N=1)\end{array}$ & & 10 & .06 \\
\hline s & NBC & $121, \underset{(N=4)}{122,130,131}$ & $\begin{array}{c}118 \\
(N=1)\end{array}$ & & & 5 & .03 \\
\hline$W$ & Weapons & $\begin{array}{c}129,143 \\
(N=2)\end{array}$ & $\begin{array}{l}33,125,126 \\
141,142,144 \\
(N-6)\end{array}$ & & & 8 & .05 \\
\hline$F$ & $\begin{array}{l}\text { Field } \\
\text { Techniques }\end{array}$ & $\begin{array}{l}74,75,76,77,78,103, \\
104,105,106,112,114, \\
115,123,124,128,134, \\
146 \\
(N=17)\end{array}$ & $\begin{array}{l}107,127 \\
(N=2)\end{array}$ & & & 19 & .11 \\
\hline$T$ & Tank Gunnery & $\begin{array}{c}4,5,9,10,17,21,22, \\
23,26,31,34,37,38, \\
39,46,79,80,83,84, \\
85,86,88,89,90,91 \\
(N=25)\end{array}$ & $\begin{array}{l}1,11,25,27, \\
29,30,32,36, \\
42,43,45,48, \\
49,73,81,82, \\
87, \quad(N=17)\end{array}$ & $\begin{array}{c}8,24,28 \\
(N=3)\end{array}$ & & 45 & .28 \\
\hline$F$ & Communication & $\begin{array}{c}57,58,59,60,61,63, \\
64,65,(N=8) .\end{array}$ & $\begin{array}{r}56,62 \\
(N=2)\end{array}$ & & & 10 & .06 \\
\hline$H$ & $\begin{array}{l}\text { Antftank/ } \\
\text { Antfair } \\
\text { Weapons }\end{array}$ & $\begin{array}{c}35,113,116,119 \\
(N=4)\end{array}$ & & & & 4 & .02 \\
\hline$S$ & Customs \& Laws & $\begin{array}{l}102,133,145,147,148, \\
149,150,151,152,153, \\
154,155,156,157,159, \\
160 \quad(N=16)\end{array}$ & $\begin{array}{c}137,138,158 \\
(N=3)\end{array}$ & & & 19 & .12 \\
\hline$F$ & $\begin{array}{l}\text { Preventive } \\
\text { maintenance }\end{array}$ & 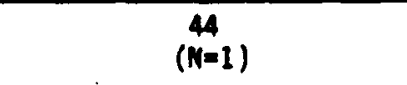 & & & & 1 & .005 \\
\hline$T$ & Operate Tanks & $\begin{array}{l}2,3,6,12,13,14,15, \\
16,19,20,40,41,47, \\
55,67,68,69,71,72 \\
109,11,136,161 \\
(N=23)\end{array}$ & $\begin{array}{c}7,18,52,53 \\
(N=6)\end{array}$ & $\begin{array}{c}50,51,54 \\
(N=3)\end{array}$ & $\begin{array}{l}66,108 \\
(N=2)\end{array}$ & 34 & .20 \\
\hline
\end{tabular}

$19 E$ 


\begin{tabular}{|c|c|c|c|c|c|c|c|}
\hline & & $\begin{array}{c}k 1 \\
k_{1}=124\end{array}$ & $\begin{array}{c}k 2 \\
K_{2}=36\end{array}$ & $\begin{array}{c}k_{3} \\
k_{3}=11\end{array}$ & $\begin{array}{c}K_{4} \\
K_{4}=4\end{array}$ & $\begin{array}{l}\text { Total N } \\
\text { of Items }\end{array}$ & 2 \\
\hline$s$ & First Aid & $\begin{array}{c}101,102,113,115,157, \\
(N=6)\end{array}$ & $\begin{array}{c}100,159 \\
(N=2)\end{array}$ & $\begin{array}{c}158 \\
(N=1)\end{array}$ & $\begin{array}{c}156 \\
(N=1)\end{array}$ & 10 & .06 \\
\hline $\mathbf{F}$ & Navi gate & $119, \underset{(N=3)}{138,168}$ & & $\begin{array}{c}120 \\
(N=1)\end{array}$ & & 4 & .02 \\
\hline $\mathbf{s}$ & NBC & $\begin{array}{c}109,111,112,114,116, \\
117,136, \\
(N=7)\end{array}$ & & & $\begin{array}{c}110 \\
(N=1)\end{array}$ & 8 & .05 \\
\hline W & Weapons & $\begin{array}{c}155 \\
(N=1)\end{array}$ & $\begin{array}{c}122,123 \\
(N=2)\end{array}$ & & & 3 & .02 \\
\hline $\mathbf{F}$ & $\begin{array}{l}\text { Field } \\
\text { Techniques }\end{array}$ & $121,133, \underset{(N=5)}{135,161,162}$ & & & $\begin{array}{c}134 \\
(N=1)\end{array}$ & 6 & .03 \\
\hline$H$ & $\begin{array}{l}\text { Antitank/ } \\
\text { Antiair } \\
\text { Weapons }\end{array}$ & $\begin{array}{c}165,166,167 \\
(N=3)\end{array}$ & $\begin{array}{c}163,164 \\
(N=2)\end{array}$ & & & 5 & .03 \\
\hline s. & Customs \& Laws & $118, \underset{(N=3)}{137,170}$ & $\begin{array}{c}169 \\
(N=1)\end{array}$ & & & 4 & .02 \\
\hline$F$ & $\begin{array}{l}\text { Preventive } \\
\text { Maintenance }\end{array}$ & $\left.86,{ }_{(N-3)}^{87}\right)^{88}$ & & & & 3 & .02 \\
\hline$T$ & Generators & $\begin{array}{c}89,90,92,96,99 \\
(N-5)\end{array}$ & $\begin{array}{c}44,91,93,95, \\
97,98 \\
(N=6),\end{array}$ & $\begin{array}{c}94 \\
(N=1)\end{array}$ & & 12 & .07 \\
\hline$T$ & $\begin{array}{l}\text { Maintain TTY } \\
\text { Electronic }\end{array}$ & $1,7, \begin{array}{c}24,79,81 \\
(N=5)\end{array}$ & $6,{ }^{80,85}{ }_{(N=3)}^{85}$ & & & 8 & .05 \\
\hline$T$ & $\begin{array}{l}\pi T \text { Station } 8 \\
\text { Net Operations }\end{array}$ & $\begin{array}{l}3,18,20,25,29,30, \\
31,33,34,35,36,47, \\
48,50,51,53,54,55, \\
56,57,58,59,60,62, \\
64,67,68,69,70,71, \\
72,73,74,75,76,77, \\
139,140,141,142,143, \\
144,147,149,150,151, \\
152,154,171,172,173, \\
174,175, \quad(N=53)\end{array}$ & $\begin{array}{l}32,49,61, \\
66,130,131 \\
132,145,148\end{array}$ & $\begin{array}{l}26,27,28, \\
52,63,65, \\
153\end{array}$ & & 69 & .39 \\
\hline$T$ & $\begin{array}{l}\text { Operate } \\
\text { Ty El ectronic } \\
\text { Equipment }\end{array}$ & $\begin{array}{c}9,12,13,14,15,16, \\
17,21,22,23,38,39, \\
40,41,42,43,46,82, \\
83,84,124,146 \\
(N=22)\end{array}$ & $\begin{array}{c}37,45,78 \\
(N=3)\end{array}$ & & & 25 & .14 \\
\hline$T$ & $\begin{array}{l}\text { Install } \\
\text { Electronte } \\
\text { Equipment }\end{array}$ & $\begin{array}{c}4,5,8,10,19,103, \\
(N=8)\end{array}$ & $\begin{array}{c}2,126,127 \\
128 \\
(N-4)\end{array}$ & $\begin{array}{c}11 \\
(N=1)\end{array}$ & & 13 & .07 \\
\hline$F$ & $\begin{array}{l}\text { Vehtcle } \\
\text { Operation } \\
\text { Recovery }\end{array}$ & & $\begin{array}{c}105 \\
(N=1)\end{array}$ & & & 1 & .005 \\
\hline$F$ & Drive & & $104, \underset{(N=3)}{106,108}$ & & $\begin{array}{c}107 \\
(N=1)\end{array}$ & 4 & .02 \\
\hline
\end{tabular}

$31 C$ 


\begin{tabular}{|c|c|c|c|c|c|c|c|}
\hline & & $\begin{array}{c}K_{1} \\
K_{1}=94\end{array}$ & $\begin{array}{c}K_{2} \\
K_{2}=56\end{array}$ & $\begin{array}{c}K 3 \\
k_{3}=19\end{array}$ & $\begin{array}{c}k 4 \\
k_{4}=3\end{array}$ & $\begin{array}{l}\text { Total N } \\
\text { of Items }\end{array}$ & $x$ \\
\hline S & First Aid & $82,86, \underset{(N=5)}{146,147,155}$ & $\begin{array}{c}87 \\
(N=1)\end{array}$ & & & 6 & .04 \\
\hline$F$ & Navigate & $\begin{array}{l}136,137,139, .140,141, \\
142,143,144,145 \\
(N=9)\end{array}$ & $\begin{array}{c}138 \\
(N=1)\end{array}$ & & & 10 & .06 \\
\hline $\mathbf{S}$ & NBC & $\begin{array}{c}165 \\
(N=1)\end{array}$ & $\begin{array}{c}166,167 \\
(N=2)\end{array}$ & & & 3 & .02 \\
\hline N & Weapons & $\begin{array}{c}149,150 \\
(\dot{N}=2)\end{array}$ & $\begin{array}{c}148, \quad 151 \\
(N=2)\end{array}$ & & & 4 & .02 \\
\hline$F$ & $\begin{array}{l}\text { Field } \\
\text { Techniques }\end{array}$ & $\begin{array}{c}79,156,160,161,162, \\
164=6)\end{array}$ & $\begin{array}{c}157 \\
(N=1)\end{array}$ & & $\begin{array}{c}153,163 \\
(N=2)\end{array}$ & 9 & .05 \\
\hline $\boldsymbol{F}$ & Communtcation & $\begin{array}{c}152 \\
(N=1)\end{array}$ & & & & 1 & .01 \\
\hline$s$ & Customs \& Laws & $159,168, \underset{(N=5)}{170,171,172}$ & $\begin{array}{c}158,169 \\
(\dot{N}=2)\end{array}$ & & & 7 & .04 \\
\hline$F$ & Drive & $\begin{array}{c}75,80,81,84,113,114, \\
115,117,119,124,127, \\
128,129,130,131,134 \\
(N=16)\end{array}$ & $\begin{array}{c}28,83,106, \\
126,132,133 \\
(N=6)\end{array}$ & $\begin{array}{r}122,135 \\
(N=2)\end{array}$ & $\begin{array}{l}154 \\
(N-1)\end{array}$ & 25 & .15 \\
\hline$F$ & $\begin{array}{l}\text { Prevent ive } \\
\text { Maintenance }\end{array}$ & $\begin{array}{c}116,118,125 \\
(N-3)\end{array}$ & & $\begin{array}{l}120,121, \\
123 \\
(N=3)\end{array}$ & & 6 & .04 \\
\hline$T$ & $\begin{array}{l}\text { Electrical } \\
\text { System. }\end{array}$ & $\begin{array}{c}88,89,90,91,92,93, \\
94,95,96 \\
(N-9)\end{array}$ & $\mid \begin{array}{c}4,26,27,30, \\
33,34,85, \\
100 \\
(N=8)\end{array}$ & $\begin{array}{r}32,9,31, \\
(N=4)\end{array}$ & • & 21 & $\begin{array}{l}.12 \\
1\end{array}$ \\
\hline$T$ & $\begin{array}{l}\text { Brake/Steering/ } \\
\text { Suspension } \\
\text { Systems }\end{array}$ & $\begin{array}{c}37,38,39,40,42,43 \\
44,45,46,47,52,76, \\
77,78,103,104,105 \\
(N=17)\end{array}$ & 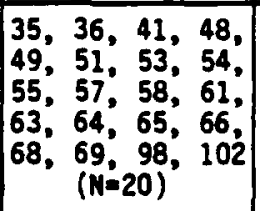 & $\begin{array}{c}50,56,59, \\
60,62,67 \\
(N=6)\end{array}$ & & 43 & .25 \\
\hline$F$ & $\begin{array}{l}\text { Vehicle } \\
\text { operation \& } \\
\text { Recovery }\end{array}$ & $\begin{array}{c}70,71,73,74 \\
(N-4)\end{array}$ & $\begin{array}{c}72 \\
(N=1)\end{array}$ & & & 5 & .03 \\
\hline$T$ & $\begin{array}{l}\text { Fuel/Cooling/ } \\
\text { Lubrtcating }\end{array}$ & $\begin{array}{c}1,3,10,14,17,18,19, \\
20,21,22,99,107,108, \\
109,110,112 \\
(N=16)\end{array}$ & \begin{tabular}{|l}
$2,11,12,13$, \\
$15,16,24,25$, \\
$29,97,101$, \\
111 \\
$(N=12)$
\end{tabular} & $\begin{array}{c}5,6,8,23 \\
(N=4)\end{array}$ & & 32 & .19 \\
\hline
\end{tabular}




\begin{tabular}{|c|c|c|c|c|c|c|c|}
\hline & & $\begin{array}{c}K I \\
K_{1}=75\end{array}$ & $\begin{array}{r}K_{2} \\
K_{2}=37\end{array}$ & $\begin{array}{c}K 3 \\
K_{3}=4\end{array}$ & $K_{4}^{K}=12$ & $\begin{array}{l}\text { Total } \\
\text { of Items }\end{array}$ & $x$ \\
\hline S & First Aid & $\begin{array}{c}97 \\
(N=1)\end{array}$ & $118, \underset{(N=3)}{119,} 120$ & & & 4 & .03 \\
\hline$F$ & Navigate & $\begin{array}{c}90,91,93,94,95,96, \\
12 i, 125, i 28 \\
(N=9)\end{array}$ & & $\begin{array}{c}92 \\
(N-1)\end{array}$ & & 10 & .08 \\
\hline 5 & NBC & $17, \underset{(M=4)}{98,}, 99,100$ & $\begin{array}{r}48,57 \\
(N=2)\end{array}$ & $\begin{array}{c}109 \\
(N=1)\end{array}$ & & 7 & .05 \\
\hline H & Heapons & 103, $\underset{(N=3)}{104,114^{\circ}}$ & $\underset{(N=2)}{105,116}$ & & & 5 & .04 \\
\hline$F$ & \begin{tabular}{|l|} 
Field \\
Techniques
\end{tabular} & $\begin{array}{c}56,110,111,112,123 \\
(N-5)\end{array}$ & $\begin{array}{c}115 \\
(N=1)\end{array}$ & & $\begin{array}{c}43,55,67 \\
68,69 ; 70 \\
(N=6)\end{array}$ & 12 & .09 \\
\hline$F$ & Comminf cation & $\begin{array}{c}122 \\
(N=1)\end{array}$ & . & & & 1 & .007 \\
\hline$W$ & $\begin{array}{l}\text { Antitank/ } \\
\text { Antiair } \\
\text { Weapons }\end{array}$ & & $\begin{array}{l}113 \\
(N=1)\end{array}$ & & & 1 & .007 \\
\hline$S$ & Custonis Laws & & & & $\begin{array}{c}108 \\
(N=1)\end{array}$ & 1 & .007 \\
\hline$F$ & Drive (Operate) & $\begin{array}{l}3,6,7,8,10,11,13, \\
15,16,18,19,21,23, \\
24,25,26,27,29,30, \\
31,35,36,37,41,49, \\
53,54,59,64,65,66, \\
75,76,77,79,82,86, \\
87,88,89,101,102, \\
106,107,124,126 \\
(M=46)\end{array}$ & $\begin{array}{l}2,4,5,9,12, \\
14,32,33,38, \\
39,40,42,45, \\
46,47,51,52, \\
72,73,74 ; 78, \\
80,81,117, \\
127 \\
(N-25)\end{array}$ & $\begin{array}{c}63,83 \\
(N-2)\end{array}$ & $\begin{array}{c}1,28,34, \\
44,50 \\
(N=5)\end{array}$ & 78 & .61 \\
\hline$F$ & $\begin{array}{l}\text { Preventive } \\
\text { Maintenance }\end{array}$ & $20, \underset{(i N=4)}{22,84,} 85$ & & & & 4 & .03 \\
\hline $\boldsymbol{F}$ & $\begin{array}{l}\text { Vehicle } \\
\text { operation \& } \\
\text { Recovery }\end{array}$ & $\begin{array}{r}58,60 \\
(N=2)\end{array}$ & $\begin{array}{c}61,62,71 \\
(N=3)\end{array}$ & & & 5 & .04 \\
\hline
\end{tabular}

$64 C$ 


\begin{tabular}{|c|c|c|c|c|c|c|c|}
\hline & & $\begin{array}{c}k_{1} \\
K_{1}=65\end{array}$ & $\begin{array}{c}K_{2} \\
K_{2}=33\end{array}$ & $\begin{array}{c}x 3 \\
x_{3}=6\end{array}$ & $K_{4}=1$ & $\begin{array}{l}\text { Total N } \\
\text { of Items }\end{array}$ & $x$ \\
\hline$S$ & First Aid & $\begin{array}{c}102 \\
(N=1)\end{array}$ & 68, $\begin{array}{l}69, \quad 105 \\
(N=3)\end{array}$ & & & 4 & .04 \\
\hline $\mathrm{F}$ & Navigate & 93, $\begin{array}{l}99,100 \\
(N=3)\end{array}$ & & $\begin{array}{c}101 \\
(N=1)\end{array}$ & & 4 & .04 \\
\hline $\mathbf{s}$ & NBC & $\begin{array}{c}67,103 \\
(N=2)\end{array}$ & $\begin{array}{c}104 \\
(N=1)\end{array}$ & & & 3 & .03 \\
\hline W & Heapons & $\begin{array}{c}57 \\
(N=1)\end{array}$ & 58, $\begin{array}{c}60,61 \\
(N=3)\end{array}$ & $\begin{array}{c}59 \\
(N=1)\end{array}$ & & 5 & .05 \\
\hline $\mathbf{F}$ & $\begin{array}{l}\text { Field } \\
\text { Techniques }\end{array}$ & $\begin{array}{c}64 \\
(N=1)\end{array}$ & $\begin{array}{c}65 \\
(N=1)\end{array}$ & & & 2 & .02 \\
\hline F & Communication & & $\begin{array}{c}66 \\
(N=1)\end{array}$ & & & 1 & .01 \\
\hline w & $\begin{array}{l}\text { Antftank/ } \\
\text { Antiair } \\
\text { Weapons }\end{array}$ & & $\begin{array}{c}63 \\
(N=1)\end{array}$ & $\begin{array}{c}62 \\
(N=1)\end{array}$ & & 2 & .02 \\
\hline $\mathbf{s}$ & Customs \& Laws & $\underset{(N=3)}{96,97,98}$ & & & & 3 & .03 \\
\hline $\mathbf{F}$ & Drive & & $\underset{(N=4)}{53,54,55,56}$ & $\begin{array}{c}52 \\
(N=1)\end{array}$ & & 5 & .05 \\
\hline$T$ & $\begin{array}{l}\text { Forms/Files } \\
\text { Management }\end{array}$ & $\begin{array}{c}45,46,47,71,72,81, \\
84,85,89,90 \\
(N=10)\end{array}$ & {$\left[\begin{array}{c}7,8,83,87,86 \\
(N=8) .\end{array}\right.$} & & $\begin{array}{c}82 \\
(N-1)\end{array}$ & 19 & .18 \\
\hline$T$ & $\begin{array}{l}\text { Supervistion/ } \\
\text { Coordination }\end{array}$ & $\begin{array}{l}70 \\
(N=1)\end{array}$ & & - & & 1 & .0 .1 \\
\hline$T$ & Correspondence & $\begin{array}{l}1,2,3,4,5,6,9,10, \\
11,12,13,17,20,21, \\
22,27,28,29,30,31, \\
32,33,34,35,36,40, \\
41,43,44,74,75,78, \\
79,80,83,91,92,94, \\
95, \quad(N=39)\end{array}$ & $\begin{array}{l}14,16,18,19 \\
24,25,26,37 \\
38,39,42\end{array}$ & $(N=2)$ & & 52 & .50 \\
\hline$T$ & $\begin{array}{l}\text { Classiffed } \\
\text { Material }\end{array}$ & 48, $\begin{array}{l}49,50,51 \\
(M=4)\end{array}$ & & & & 4 & .04 \\
\hline
\end{tabular}

71L 


\begin{tabular}{|c|c|c|c|c|c|c|c|}
\hline & & $\begin{array}{c}K 1 \\
K 1=125\end{array}$ & $\begin{array}{c}K_{2} \\
K_{2}=41\end{array}$ & $\begin{array}{c}k 3 \\
K_{3}=2\end{array}$ & $\begin{array}{c}K 4 \\
K_{4}=7\end{array}$ & $\begin{array}{l}\text { Total N } \\
\text { of Items }\end{array}$ & $x$ \\
\hline$S$ & First Aid & $74, \underset{(N=3)}{123,} 145$ & $\begin{array}{r}18,75 \\
(N=2)\end{array}$ & & & 5 & .03 \\
\hline$F$ & Navigate & $\begin{array}{l}76 \\
(N=1)\end{array}$ & & & & 1 & .005 \\
\hline$s$ & NBC & $\begin{array}{r}57,60 \\
(N=2)\end{array}$ & $\begin{array}{l}58 \\
(N=1)\end{array}$ & & $\begin{array}{c}59 \\
(N=1)\end{array}$ & 4 & .02 \\
\hline F & $\begin{array}{l}\text { Field } \\
\text { Techntques }\end{array}$ & & $\begin{array}{c}56 \\
(N=1)\end{array}$ & & & 1 & .005 \\
\hline 5 & Customs \& Laws & & & & $\begin{array}{c}77 \\
(N=1)\end{array}$ & 1 & .005 \\
\hline$F$ & Drive & $47,49,52,53,54,55$ & $\begin{array}{r}50,51 \\
(N=2)\end{array}$ & & $\begin{array}{c}48 \\
(N=1)\end{array}$ & 9 & .05 \\
\hline$T$ & $\begin{array}{l}\text { ClinteNard } \\
\text { Treatment \& } \\
\text { Care }\end{array}$ & $\begin{array}{l}1,7,8,10,11,12,13, \\
15,17,23,24,25,28, \\
29,30,31,32,34,61, \\
64,71,73,88,89,94, \\
99,100,101,104,106, \\
107,109,111,112,118, \\
119,121,124,125,129, \\
132,133,134,135,136, \\
138,140,141,142,152, \\
158,161,162,163,169, \\
173, \\
(N=56)\end{array}$ & $\begin{array}{l}14,19,33,37, \\
66,67,70,84, \\
92,98,102, \\
103,105,108, \\
110,120,122, \\
126,127,137, \\
144,146,151, \\
153,166,168, \\
172,174 \\
(N=28)\end{array}$ & $\begin{array}{l}36,93 \\
(N=2)\end{array}$ & $16,35,149$ & 89 & .51 \\
\hline$T$ & $\begin{array}{l}\text { Clinic/Mard } \\
\text { Housekeepting }\end{array}$ & $\begin{array}{c}27,38,42,43,72,113, \\
114,115, i 16,117,150 \\
(N=1 i)\end{array}$ & $\begin{array}{c}39,46,15541 . \\
45,46,155 \\
(N=7)\end{array}$ & . & $\begin{array}{c}26 \\
(N=1)\end{array}$ & 15 & .09 \\
\hline$T$ & $\begin{array}{l}\text { Clinic/Mard } \\
\text { Management }\end{array}$ & $\begin{array}{l}2,3,5,6,9,20,21, \\
22,44,170, \underset{(N=10)}{ }\end{array}$ & $\begin{array}{c}4,40,41,45 \\
(N=4)\end{array}$ & & & 14 & .08 \\
\hline$T$ & $\begin{array}{l}\text { General Medical } \\
\text { Knowledge }\end{array}$ & $\begin{array}{l}62,63,65,68,69,78, \\
79,80,81,82,83,85, \\
86,87,90,91,95,96, \\
97,128,130,131,139, \\
143,147,148,154,156, \\
157,159,160,164,165, \\
167,171,175,(N=36)\end{array}$ & & & & 36 & .21 \\
\hline
\end{tabular}




\begin{tabular}{|c|c|c|c|c|c|c|c|}
\hline & & $R_{1}=81$ & $K_{2}=42$ & $k_{3}=11$ & $K_{4}=5$ & of Items & 8 \\
\hline 5 & First Aid & $\begin{array}{l}100,101,107,110,111, \\
112,114, \begin{array}{l}116,132 \\
(N=9)\end{array}\end{array}$ & $\begin{array}{l}109,115,117 \\
130,131,134 \\
(N=6)\end{array}$ & & $\begin{array}{c}113 \\
(N=1)\end{array}$ & 16 & .12 \\
\hline$F$ & Navigate & $\begin{array}{c}79,89,119,120,127 \\
(N=5)\end{array}$ & & $\begin{array}{c}121,128 \\
129 \\
(N=3)\end{array}$ & & 8 & .06 \\
\hline$s$ & NBC & $\begin{array}{c}98,103,105,118,125, \\
126 \\
(N=6)\end{array}$ & $\begin{array}{c}99,102,104 \\
(N=3)\end{array}$ & & & 9 & .06 \\
\hline$w$ & Heapons & 93, $\frac{95,96,97}{(N=4)}$ & $\begin{array}{c}92,133 \\
(N=2)\end{array}$ & $\begin{array}{l}91.94 \\
(N=2)\end{array}$ & & 8 & .06 \\
\hline$F$ & $\begin{array}{l}\text { Field } \\
\text { Techntques }\end{array}$ & $\begin{array}{c}14,22,70,71,72,74, \\
124=7)\end{array}$ & & & $\begin{array}{c}73 \\
(N=1)\end{array}$ & 8 & .06 \\
\hline$F$ & Communteation & $\begin{array}{c}66,106 \\
(N=2)\end{array}$ & $\begin{array}{c}69 \\
(N=1)\end{array}$ & $\begin{array}{l}67,68 \\
(N=2)\end{array}$ & & 5 & .04 \\
\hline$w$ & $\begin{array}{l}\text { Antttank/ } \\
\text { Antlair } \\
\text { Weapons }\end{array}$ & $\begin{array}{c}135,136,138 \\
(N=3)\end{array}$ & $\begin{array}{c}137 \\
(N=1)\end{array}$ & $\begin{array}{l}139 \\
(N=1)\end{array}$ & & 5 & .04 \\
\hline$S$ & Custons \& Laws & $\begin{array}{c}122 \\
(N=1)\end{array}$ & $\begin{array}{c}78 \\
(M=1)\end{array}$ & & $\begin{array}{l}75,76 \\
(N=2)\end{array}$ & 4 & .03 \\
\hline $\mathbf{F}$ & Orive & $63,83,84, \underset{(N \sim 6)}{85}, 90,108$ & $\begin{array}{c}80,81,86,88 \\
(N=4)\end{array}$ & & & 10 & .07 \\
\hline $\mathbf{F}$ & $\begin{array}{l}\text { Prevent ive: } \\
\text { Maintenance }\end{array}$ & $\begin{array}{c}82 \\
(N=1)\end{array}$ & & & & 1 & .007 \\
\hline $\mathbf{F}$ & $\begin{array}{l}\text { Vehtcle } \\
\text { Operation } \\
\text { Recovery }\end{array}$ & $\begin{array}{c}87 \\
(N=1)\end{array}$ & & & & 1 & .007 \\
\hline$T$ & $\begin{array}{l}\text { Responding to } \\
\text { Alarms }\end{array}$ & 17, $\underset{(N=4)}{20,64}$ & $4,2_{(i=3)}^{24,43}$ & & & 7 & .05 \\
\hline$T$ & $\begin{array}{l}\text { Conduct MP } \\
\text { Procedures }\end{array}$ & $\begin{array}{l}5,6,8,9,11,15,21, \\
29,30,33,35,38,39, \\
40,45,46,47,48,49, \\
51,55,56,59,60,77, \\
123 \quad(N=26)\end{array}$ & $\begin{array}{c}1,3,16,28, \\
25,26,28,31, \\
36,37,44,50, \\
52,54,57,58 \\
(N=16)\end{array} \mid$ & $(N-3)$ & $\begin{array}{l}53 \\
(N=1)\end{array}$ & 46 & .33 \\
\hline$T$ & Patrol Duties & $\begin{array}{c}2,23,34,41,61,62 \\
(N=6)\end{array}$ & $\mid \begin{array}{c}12,13,27,42 \\
65 \\
(N=5)\end{array}$ & & & 11 & .08 \\
\hline
\end{tabular}




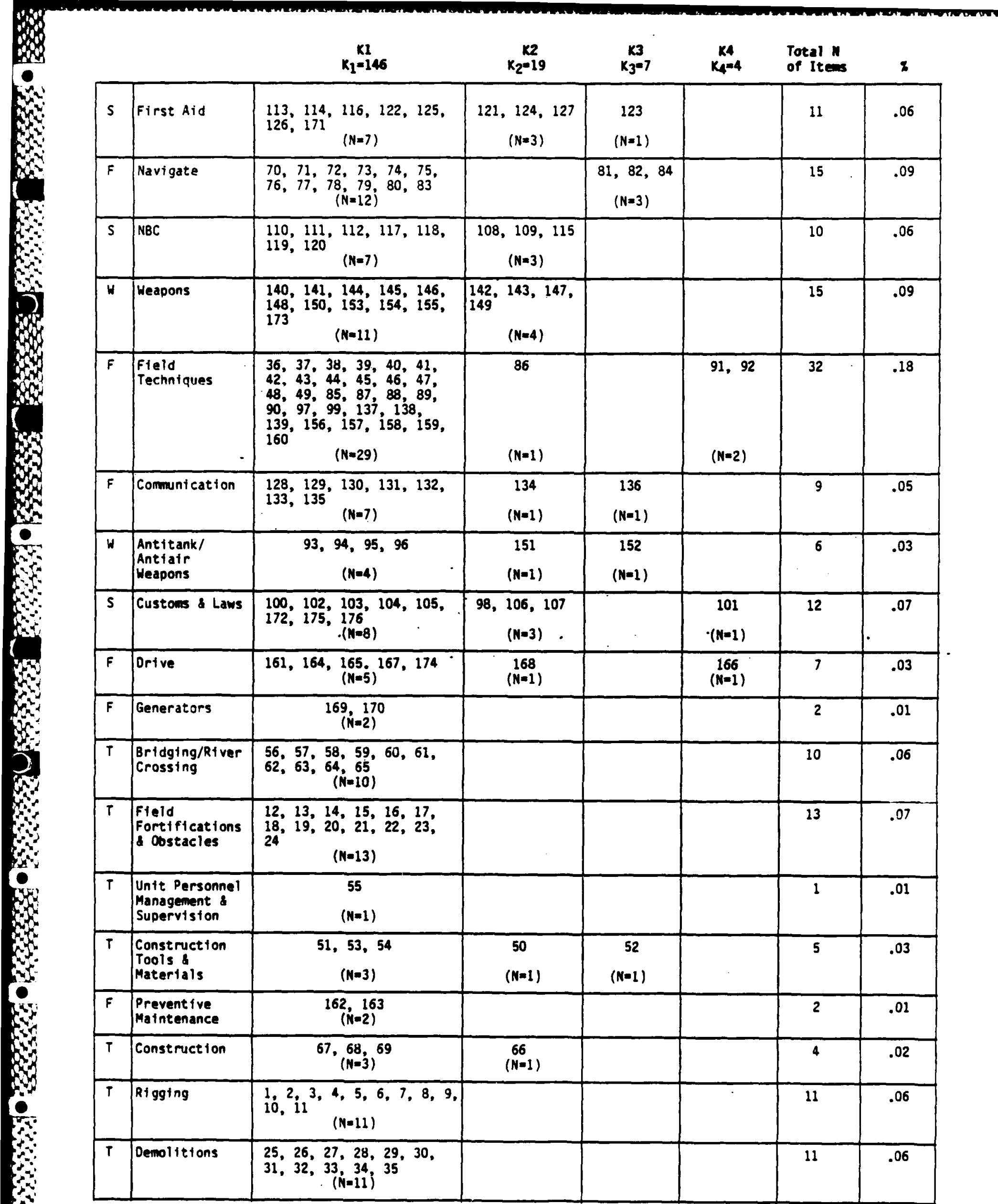




\begin{tabular}{|c|c|c|c|c|c|c|c|}
\hline & & $\begin{array}{c}K 1 \\
K_{1}=122\end{array}$ & $\begin{array}{c}K_{2} \\
K_{2}=16\end{array}$ & $\begin{array}{c}k 3 \\
K_{3}=8\end{array}$ & $\begin{array}{c}x_{4} \\
x_{4}=3\end{array}$ & $\begin{array}{l}\text { Total N } \\
\text { of Items }\end{array}$ & 2 \\
\hline 5 & First Aid & $\begin{array}{l}115,125,126,128,147, \\
148,149 \underset{(N=7)}{ }\end{array}$ & $\begin{array}{c}124,127,144 \\
(N=3)\end{array}$ & & & 10 & .07 \\
\hline$F$ & Navigate & $\begin{array}{c}76,77,78,79,80,81, \\
82,83,84,85,86 \\
(N=11)\end{array}$ & & $\begin{array}{l}87,88,89 \\
(N=3)\end{array}$ & & 14 & .09 \\
\hline 5 & MBC & 129. $\underset{(N=3)}{130,131}$ & $\begin{array}{c}132 \\
(N=1)\end{array}$ & & & 4 & .03 \\
\hline$W$ & Weapons & $116, \underset{(N=3)}{118,} 145$ & $\begin{array}{l}117 \\
(N=1)\end{array}$ & & & 4 & .03 \\
\hline $\mathbf{F}$ & $\begin{array}{l}\text { Fteld } \\
\text { Techniques }\end{array}$ & $\begin{array}{l}64,65,121,122,123, \\
135,136,137,139,140, \\
141 \\
(N=11)\end{array}$ & & & $(N=1)$ & 12 & .08 \\
\hline $\mathbf{F}$ & Communications & $90,91, \underset{(N=5)}{92,93,95}$ & 94, $\underset{(N=3)}{98,99}$ & $\begin{array}{l}96,97 \\
(N=2)^{97}\end{array}$ & & 10 & .07 \\
\hline W & $\begin{array}{l}\text { Antitank/ } \\
\text { Antiair } \\
\text { Weapons }\end{array}$ & $\begin{array}{l}1,2,3,4,5,14,20,68, \\
69,70,71,72,73,74, \\
75,133,134, \\
(N=17)\end{array}$ & $\begin{array}{l}119,146 \\
(N=2)\end{array}$ & $\begin{array}{l}120 \\
(N=1)\end{array}$ & & 20 & .13 \\
\hline$s$ & $\begin{array}{l}\text { Customs and } \\
\text { Laws }\end{array}$ & $\begin{array}{c}142 \\
(N=1)\end{array}$ & & & $\begin{array}{c}143 \\
(N=1)\end{array}$ & 2 & .01 \\
\hline $\mathbf{F}$ & Drive & $\begin{array}{l}102,103,107,108,110 \\
111,112, \underset{(N-9)}{113}, 114\end{array}$ & $\begin{array}{c}109 \\
(N=1)\end{array}$ & & & 10 & .07 \\
\hline$T$ & Redeye & $\begin{array}{c}6,8,9,10,11,13,15, \\
18,19,21,22,23,24, \\
25,26,27,28,30,31 \\
(N=19)\end{array}$ & $\begin{array}{l}7,12,29 \\
(N=3)\end{array}$ & $\begin{array}{l}16,17 \\
(N=2)\end{array}$ & & 24 & .17 \\
\hline$T$ & Stinger & $\begin{array}{l}41,42,44,45,46,47, \\
48,49,50,51,52,53, \\
54,55,56,57,58,59, \\
60,61,62,63,67 \\
(N=23)\end{array}$ & $(N=1)$ & & $(N=1)$ & 25 & .17 \\
\hline$T$ & TADOS & 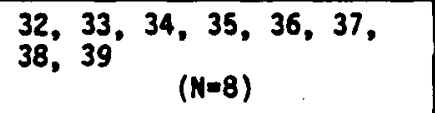 & $\begin{array}{c}40 \\
(N=1)\end{array}$ & & & 9 & .06 \\
\hline $\mathbf{F}$ & $\begin{array}{l}\text { Preventive } \\
\text { Maintenance }\end{array}$ & $100,101, \underset{(N=5)}{104,105,106}$ & & & & 5 & .03 \\
\hline
\end{tabular}




\begin{tabular}{|c|c|c|c|c|c|c|c|}
\hline & & $\begin{array}{c}K 1 \\
K_{1}=140\end{array}$ & $\begin{array}{c}K_{2} \\
x_{2}=20\end{array}$ & $\begin{array}{c}K_{3} \\
K_{3}=15\end{array}$ & $\begin{array}{c}x_{4} \\
x_{4}=0\end{array}$ & $\begin{array}{l}\text { Total N } \\
\text { of Items }\end{array}$ & 2 \\
\hline$S$ & First Aid & $\begin{array}{c}130,143,144,145,147, \\
159,161, \underset{(N=7)}{ }\end{array}$ & $\begin{array}{c}142,146 \\
(N=2)\end{array}$ & & & 9 & .05 \\
\hline$F$ & Navigate & $\begin{array}{c}131,132,133,135,136, \\
137,138,139,140,141 \\
(N=10)\end{array}$ & & $\begin{array}{c}134 \\
(N=1)\end{array}$ & & 11 & .06 \\
\hline$s$ & NBC & $\begin{array}{c}158,160 \\
(\dot{N}=2)\end{array}$ & $\begin{array}{c}157 \\
(N=1)\end{array}$ & & & 3 & .02 \\
\hline W & Weapons & 148, $\underset{\substack{149,(N=4)}}{150,} 152$ & $\begin{array}{c}151 \\
(N=1)\end{array}$ & & & 5 & .03 \\
\hline $\mathbf{F}$ & $\begin{array}{l}\text { Field } \\
\text { Techniques }\end{array}$ & 153, $162,163,164$ & & & & 4. & .02 \\
\hline $\mathbf{F}$ & Communication & $165,166, \underset{(N=5)}{167,168,169}$ & & & & 5 & .03 \\
\hline$W$ & $\begin{array}{l}\text { Antitank/ } \\
\text { Antiair } \\
\text { Weapons }\end{array}$ & $\begin{array}{c}156,170,171,172,173 \\
(N=5)\end{array}$ & $\begin{array}{c}155 \\
(N=1)\end{array}$ & & & 6 & .03 \\
\hline 5 & Customs \& Laws & $\begin{array}{c}174,175 \\
(N=2)\end{array}$ & & & & 2 & .01 \\
\hline $\mathbf{F}$ & Drive & $115, \underset{(N-3)}{128,} 129$ & $125, \underset{(N=3)}{126}, 127$ & & & 6 & .03 \\
\hline F & $\begin{array}{l}\text { Preventive } \\
\text { Maintenance }\end{array}$ & $\begin{array}{l}110,111,112,113,114, \\
116,117,118,119,120, \\
121,122,123,1(N=13)\end{array}$ & & $\begin{array}{l}124 \\
(N-1)\end{array}$ & & 14 & .08 \\
\hline$T$ & $\begin{array}{l}\text { TOW Components, } \\
\text { TOW Test }\end{array}$ & $\begin{array}{l}28,29,30,31,32,33, \\
34,35,38,41,43,44, \\
45,57,58,59,60,61 \\
62,63,64,65,66,67, \\
68,105,106,107,108, \\
109, \\
(N=30)\end{array}$ & $\begin{array}{c}36,37,39,40, \\
42,56,69 \\
(N=7)\end{array}$ & $\theta$ & & 37 & .21 \\
\hline$T$ & $\begin{array}{l}\text { Training } \\
\text { Equipment \& } \\
\text { Simulators } \\
\text { (TOW) }\end{array}$ & $\begin{array}{c}46,47,48,49,50,51, \\
52,54,55 \\
(N=9)\end{array}$ & $\begin{array}{l}53 \\
(N=1)\end{array}$ & & & 10 & .06 \\
\hline$T$ & $\begin{array}{l}\text { Dragon } \\
\text { Components }\end{array}$ & $\begin{array}{c}70,71,72,73,74,76, \\
77,78,79,80,81,82, \\
83,84,100,101,102, \\
103,104,(N=19)\end{array}$ & $75,98,154$ & $\begin{array}{l}99 \\
(N=1)\end{array}$ & & 23 & .13 \\
\hline$T$ & $\begin{array}{l}\text { Dragon Test } \\
\text { Simulators }\end{array}$ & $\begin{array}{c}85,86,87,88,89,90, \\
91,92,93,94,95,96, \\
97 \\
(N=13)\end{array}$ & & & & 13 & .07 \\
\hline$T$ & Electronies & $\begin{array}{c}1,2,3,5,9,11,15,17 \\
20,21,23,24,25,27 \\
(N=14)\end{array}$ & $(N=1)$ & $\begin{array}{l}4,6,7,8, \\
10,12,13, \\
14,16,18, \\
19,26 \\
(N=12)\end{array}$ & & 27 & .15 \\
\hline
\end{tabular}




\begin{tabular}{|c|c|c|c|c|c|c|c|}
\hline & • & $\begin{array}{c}K 1 \\
K_{1}=127\end{array}$ & $\frac{k 2}{k 2^{-14}}$ & $\begin{array}{c}k 3 \\
k_{3}=21\end{array}$ & $K_{4}^{K}=1$ & $\begin{array}{l}\text { Total N } \\
\text { of Items }\end{array}$ & 8 \\
\hline $\mathbf{s}$ & First Aid & $\begin{array}{c}147,148 \\
(N=2)\end{array}$ & $\begin{array}{c}151, \quad 153 \\
(\dot{N}=2)\end{array}$ & $\begin{array}{c}152 \\
(N=1)\end{array}$ & & 5 & .03 \\
\hline$F$ & Navigate & $\begin{array}{c}117,119,120,121,122, \\
(N=6)\end{array}$ & & $\begin{array}{l}118,123 \\
(N=2)\end{array}$ & & 8 & .05 \\
\hline$S$ & NBC & $146, \underset{(N=3)}{149,150}$ & $\begin{array}{c}145 \\
(N=1)\end{array}$ & & & 4 & .03 \\
\hline$H$ & Weapons & 136, $\underset{(N=3)}{137,} 138$ & & & & 3 & .02 \\
\hline $\mathbf{F}$ & $\begin{array}{l}\text { Field } \\
\text { Techniques }\end{array}$ & $\begin{array}{c}\text { 108, 109, 110, 111, 113, } \\
\text { 115, 116, 135, 141, 142, } \\
143,144,(N=12)\end{array}$ & $\begin{array}{l}112,114 \\
(N=2)\end{array}$ & & & 14 & .09 \\
\hline$F$ & Communications & $161, \underbrace{162,163}_{(N=3)}$ & & & & 3 & .02 \\
\hline$W$ & $\begin{array}{l}\text { Antitank/ } \\
\text { Antiair } \\
\text { Weapons }\end{array}$ & $\begin{array}{c}133,134 \\
(N=2)\end{array}$ & $\begin{array}{c}139 \\
(N=1)\end{array}$ & $\begin{array}{c}140 \\
(N=1)\end{array}$ & & 4 & .03 \\
\hline$s$ & $\begin{array}{l}\text { Customs and } \\
\text { Laws }\end{array}$ & $\begin{array}{c}154,155,156,157,159, \\
160 \\
(N=6)\end{array}$ & $\begin{array}{c}158 \\
(N=1)\end{array}$ & & & 7 & .04 \\
\hline $\mathbf{F}$ & Orive & 127, $\cos _{(N=3)}^{128}$ & $\begin{array}{c}131 \\
(N=1)\end{array}$ & & $\begin{array}{c}130 \\
(N=1)\end{array}$ & 5 & .03 \\
\hline$F$ & Generators & $\begin{array}{c}126 \\
(N=1)\end{array}$ & $\begin{array}{c}125 \\
(N=1)\end{array}$ & & & 2 & .01 \\
\hline$F$ & \begin{tabular}{|l} 
Preventive \\
Maintenance
\end{tabular} & $\begin{array}{c}129 \\
(N=1)\end{array}$ & & & . & 1 & .01 \\
\hline$T$ & $\begin{array}{l}\text { Construction } \\
\text { Tools \& } \\
\text { Materials }\end{array}$ & $\begin{array}{c}25,31,32,33,34,35, \\
37,38,54,55,72 \\
(N=11)\end{array}$ & $\begin{array}{c}30 \\
(N=1)\end{array}$ & $\begin{array}{l}17,18,19, \\
36,68 \\
(N=5)\end{array}$ & & 17 & .10 \\
\hline$T$ & Construction & $\begin{array}{l}1,2,3,4,6,7,8,20, \\
21,22,23,24,26,27, \\
28,29,39,40,41,42, \\
43,44,45,46,47,48, \\
49,50,51,52,56,57, \\
58,59,60,61,62,63, \\
64,65,69,70,73,74, \\
75,76,77,79,80,81, \\
82,84,85,86 \\
(\hat{N}=54)\end{array}$ & $(N=4)$ & $\begin{array}{c}5,66,67, \\
(N=4)\end{array}$ & & 62 & .38 \\
\hline$T$ & Rigging & $88,89, \underset{(N=6)}{90,91,92,93}$ & & & & 6 & .04 \\
\hline$T$ & Math & & & $\begin{array}{l}9,10,11 \\
12,13,14 \\
15,16, \\
(N=8)\end{array}$ & & 8 & .05 \\
\hline$T$ & Demolition & $\begin{array}{c}94,95,96,97,98,99 \\
100,101,102,103,104 \\
105, \\
(N=12)\end{array}$ & & & & 12 & .07 \\
\hline T. & $\begin{array}{l}\text { Field } \\
\text { Fortifications } \\
\text { \& Obstacles }\end{array}$ & $\begin{array}{c}106,107 \\
(N=2)\end{array}$ & & & & 2 & .01 \\
\hline
\end{tabular}




\begin{tabular}{|c|c|c|c|c|c|c|c|}
\hline & & $\begin{array}{c}K 1 \\
K_{1}=112\end{array}$ & $\begin{array}{c}k_{2} \\
K_{2}=17\end{array}$ & $\begin{array}{c}k 3 \\
k_{3}=14\end{array}$ & $\begin{array}{c}k 4 \\
k_{4}=2\end{array}$ & $\begin{array}{l}\text { Total N } \\
\text { of Itens }\end{array}$ & 2 \\
\hline$S$ & $\begin{array}{c}\text { First Aid } \\
\text {. }\end{array}$ & 47. $\begin{array}{c}48,125 \\
(N=3)\end{array}$ & 46, $\begin{array}{l}124,127 \\
(N=3)\end{array}$ & $\begin{array}{c}126 \\
(N=1)\end{array}$ & & 7 & .05 \\
\hline$F$ & Navigate & $\begin{array}{c}64,65,67,68,69,72, \\
73,75,76,77,80 \\
(N=11)\end{array}$ & $\begin{array}{c}63 \\
(N=1)\end{array}$ & $\begin{array}{c}66,70,71 \\
74,78,79 \\
(N=6)\end{array}$ & & 18 & .12 \\
\hline$S$ & NBC & $\begin{array}{c}\frac{1}{43,2}, 44,4,30,31,32, \\
(N=9)\end{array}$ & $\begin{array}{c}45 \\
(N=1)\end{array}$ & & & 10 & .07 \\
\hline$w$ & Weapons & $\begin{array}{c}105,106,108,109,110, \\
112 \\
(N=6)\end{array}$ & $\begin{array}{c}107,111 \\
(N=2)\end{array}$ & & & 8 & .05 \\
\hline$F$ & $\begin{array}{l}\text { Field } \\
\text { Techniques }\end{array}$ & $\begin{array}{l}113,114,115,117,118, \\
119,120,121,122,123, \\
131,132,141,142,\end{array}$ & & & & 14 & .10 \\
\hline$F$ & Communt cations & $83,84, \underset{(N=6)}{85,86,87,88}$ & $\begin{array}{c}89 \\
(N=1)\end{array}$ & $\begin{array}{l}81,82 \\
(N=2)\end{array}$ & & 9 & .06 \\
\hline$W$ & $\begin{array}{l}\text { Antitank/ } \\
\text { Antiair } \\
\text { Weapons }\end{array}$ & $\begin{array}{c}128,129,130 \\
(N=3)\end{array}$ & $\begin{array}{c}116 \\
(N=1)\end{array}$ & & & 4 & .03 \\
\hline$s$ & $\begin{array}{l}\text { Customs and } \\
\text { Laws }\end{array}$ & $\begin{array}{c}134,135,136,137,138 \\
139,140,143,144,145 \\
(N=10)\end{array}$ & $\begin{array}{c}133 \\
(N=1)\end{array}$ & & & 11 & .08 \\
\hline $\bar{F}$ & Drive & $\underset{\substack{100 \\
(N=2)}}{101}$ & $\begin{array}{c}99 \\
(N=1)\end{array}$ & & & 3 & .02 \\
\hline$F$ & Generators & $\begin{array}{c}102,103 \\
(N=2)\end{array}$ & $\begin{array}{c}104 \\
(N=1)\end{array}$ & . & & 3 & .02 \\
\hline$T$ & $\begin{array}{l}\text { Chemical/ } \\
\text { Bfological/ } \\
\text { Radiological } \\
\text { Operations }\end{array}$ & $\begin{array}{c}5,6,8,9,10,1112,15, \\
16,17,18,19,20,22, \\
24,25,27,28,29,33, \\
34,35,37,38,39,40, \\
42 \quad(N=27)\end{array}$ & $14,36,41$ & $\begin{array}{c}7,13,21, \\
23,26)\end{array}$ & & 35 & .24 \\
\hline$T$ & $\begin{array}{l}\text { Decontamination } \\
\text { Operations } \\
\text { Equipment }\end{array}$ & $\begin{array}{c}49,50,51,53,55,56, \\
57,58,59,61 ; 62 \\
(N=11)\end{array}$ & $\begin{array}{l}52,54 \\
(N=2)\end{array}$ & & $\begin{array}{c}60 \\
(N=1)\end{array}$ & 14 & .10 \\
\hline$F$ & $\begin{array}{l}\text { Preventive } \\
\text { Maintenance }\end{array}$ & $\begin{array}{c}90,91,92,93,94,95, \\
96,97 \\
(N=8)\end{array}$ & & & $\begin{array}{c}98 \\
(N=1)\end{array}$ & 9 & .06 \\
\hline
\end{tabular}




\begin{tabular}{|c|c|c|c|c|c|c|c|}
\hline & & $\begin{array}{c}K 1 \\
K_{1}=152\end{array}$ & $\begin{array}{c}K_{2} \\
K_{2}=21\end{array}$ & $\begin{array}{c}k_{3} \\
k_{3}=2\end{array}$ & $\begin{array}{c}K_{4}^{4} \\
K_{4}=0\end{array}$ & $\begin{array}{l}\text { Total N } \\
\text { of Items }\end{array}$ & 8 \\
\hline$s$ & First Aid & $\begin{array}{c}13,157 \\
(\hat{N}=2)\end{array}$ & $\begin{array}{l}29,161 \\
(N=2)\end{array}$ & $\begin{array}{c}160 \\
(N=1)\end{array}$ & & 5 & .03 \\
\hline$F$ & Navigate & $\begin{array}{l}142,144,145,146,147, \\
148,149, \begin{array}{l}150 \\
(N=8)\end{array}\end{array}$ & & $\begin{array}{c}143 \\
(N=1)\end{array}$ & & 9 & .05 \\
\hline $\mathbf{S}$ & NBC & $\begin{array}{c}158 \\
(N=1)\end{array}$ & $\begin{array}{c}156,159 \\
(N=2)\end{array}$ & & & 3 & .02 \\
\hline$W$ & Weapons & $\begin{array}{c}151 \\
(N=1)\end{array}$ & $\begin{array}{c}152 \\
(N=1)\end{array}$ & & & 2 & .01 \\
\hline$F$ & $\begin{array}{l}\text { Field } \\
\text { Techniques }\end{array}$ & $\begin{array}{c}153,155,164,166,167, \\
168,171,173,(N=8)\end{array}$ & & & & 8 & .05 \\
\hline$F$ & Communications & $122, \underset{(M=4)}{123,124,125}$ & $\begin{array}{c}121 \\
(N=1)\end{array}$ & & & 5 & .03 \\
\hline$W$ & $\mid \begin{array}{l}\text { Antitank/ } \\
\text { Antiair Weapons }\end{array}$ & $\begin{array}{c}162,163 \\
(N=2)\end{array}$ & $\begin{array}{c}154 \\
(N=1)\end{array}$ & & & 3 & .02 \\
\hline $\mathbf{S}$ & $\begin{array}{l}\text { Customs and } \\
\text { Laws }\end{array}$ & $165,169, \underset{(N=5)}{170,174,175}$ & $\begin{array}{c}172 \\
(N=1)\end{array}$ & & & 6 & .03 \\
\hline$T$ & $\begin{array}{l}\text { Helicopter } \\
\text { Maintenance }\end{array}$ & $\begin{array}{l}14,15,16,17,18,19, \\
20,21,22,32,33,34, \\
36,39,40,41,42,43, \\
44,45,47,48,49,50, \\
51,52,53,54,55,56, \\
57,58,59,60,61,62, \\
64,65,66,67,68,69, \\
70,71,72,73,74,76, \\
77,78,80,81,82,83, \\
84,85,86,87,89,90, \\
92,93,94,95,96,97, \\
98,99,100,101,102, \\
103,104,105,106,109, \\
110,11,112,113,114,- \\
115,116,117,118,119, \\
126,127,128,129,130, \\
132,133,134,135,136 \\
(N=96)\end{array}$ & $\begin{array}{l}35,37,38,63 \\
75,79,88,91 \\
107,108,120\end{array}$ & . & & $\cdot$ & .61 \\
\hline$T$ & $\begin{array}{l}\text { Aircraft } \\
\text { Maint. Admin. }\end{array}$ & $\begin{array}{l}1,2,3,4,5,6,7,8, \\
9,10,11,12,131 \\
(N=13)\end{array}$ & & & & 13 & .07 \\
\hline$T$ & Aircraft Refuel & 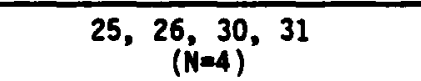 & & & & 4 & .02 \\
\hline$T$ & $\begin{array}{l}\text { Landing/ } \\
\text { Takeoff Si gnals }\end{array}$ & $\begin{array}{r}23,24 \\
(N=2)\end{array}$ & & & & 2 & .01 \\
\hline$T$ & $\begin{array}{l}\text { Aireraft Maint. } \\
\text { Tools/Equip. }\end{array}$ & $27,28,46, \underset{(N=6)}{137}, 140,141$ & $\begin{array}{c}138,139 \\
(\dot{N}=2)\end{array}$ & & & 8 & .05 \\
\hline
\end{tabular}

671 


\begin{tabular}{|c|c|c|c|c|c|c|c|}
\hline & & $\begin{array}{c}x_{1} \\
x_{1}=151\end{array}$ & $\begin{array}{c}k_{2} \\
k_{2}=14\end{array}$ & $\begin{array}{c}K_{3} 3 \\
K_{3}=7\end{array}$ & $K_{4}^{K=3}$ & $\begin{array}{l}\text { Total N } \\
\text { of Items }\end{array}$ & $x$ \\
\hline$S$ & First Aid & 30, $\underset{(N=4)}{31,32,164}$ & $\begin{array}{c}163 \\
(N=1)\end{array}$ & $\begin{array}{c}162 \\
(N=1)\end{array}$ & & 6 & .03 \\
\hline $\mathbf{F}$ & Navigate & $144,146, \underset{(N=5)}{147,172,173}$ & & $\begin{array}{c}145 \\
(N=1)\end{array}$ & & 6 & .03 \\
\hline$W$ & Weapons & $\begin{array}{c}148,149,150,151,152, \\
153,174,(N=7)\end{array}$ & $\begin{array}{c}156 \\
(N=1)\end{array}$ & & & 8 & .05 \\
\hline $\mathbf{F}$ & $\begin{array}{l}\text { Field } \\
\text { Teehniques }\end{array}$ & $\begin{array}{l}138,154,155,158,159, \\
160,161, \begin{array}{l}175 \\
(N=8)\end{array}\end{array}$ & & & & 8 & .05 \\
\hline $\mathbf{F}$ & Conmunications & 142, $\underset{(N=3)}{143,171}$ & & & & 3 & .02 \\
\hline$W$ & \begin{tabular}{|l|} 
Antitank/ \\
Antiair Weapons
\end{tabular} & $139, \underset{(N=3)}{140,141}$ & & $\begin{array}{c}157 \\
(N=1)\end{array}$ & & 4 & .02 \\
\hline$S$ & $\begin{array}{l}\text { Customs and } \\
\text { Laws }\end{array}$ & $166, \underset{\substack{1 \\
(N=4)}}{1689}, 170$ & & & $\begin{array}{c}165,167 \\
(N=2)\end{array}$ & 6 & .03 \\
\hline$F$ & Drive & $132, \begin{array}{c}134,136,137 \\
(N=4)\end{array}$ & $\begin{array}{c}135 \\
(N=1)\end{array}$ & & $\begin{array}{c}133 \\
(N=1)\end{array}$ & 6 & .03 \\
\hline $\mathrm{T}$ & $\begin{array}{l}\text { Landing/Takeoff } \\
\text { Signals }\end{array}$ & $\begin{array}{r}50,51 \\
(\dot{N}=2)\end{array}$ & & & & 2 & .01 \\
\hline$T$ & $\begin{array}{l}\text { POL Stte } \\
\text { Operation }\end{array}$ & $\begin{array}{l}3,5,11,12,14,22,23 \\
35,66,67,72,99,100, \\
102,104,106,107,109, \\
111,112,113,114,115, \\
116,117, \quad(N=25)\end{array}$ & $\begin{array}{l}82,98,108, \\
110 \\
. \quad(N-4)\end{array}$ & • & & 29 & .17 \\
\hline$T$ & $\begin{array}{l}\text { POL Storage \& } \\
\text { Administration }\end{array}$ & $\begin{array}{l}33,36,37,38,40,41, \\
42,45,54,55,56,577, \\
58,59,60,61,62,63, \\
64,65,68,69,70,71, \\
85,88,118,119,120, \\
121,122,123,124,125, \\
126,127,128 \\
(N=37)\end{array}$ & $(N=1)$ & $\begin{array}{c}73,74,129, \\
130^{\circ} \\
(N=4)\end{array}$ & & 42 & .24 \\
\hline$T$ & $\begin{array}{l}\text { POL Equipment } \\
\text { Maintenance }\end{array}$ & $\begin{array}{c}1,13,16,17,18,20, \\
24,44,101,103 \\
(N=10)\end{array}$ & $\begin{array}{r}15,19 \\
(N=2)\end{array}$ & & & 12 & .07 \\
\hline$T$ & $\begin{array}{l}\text { POL Issue/ } \\
\text { Turn-in/ } \\
\text { Transfer }\end{array}$ & $\begin{array}{c}2,39,47,48,49,52, \\
53,84,95,97,105,131 \\
(N=12)\end{array}$ & $\begin{array}{l}4,96 \\
(N=2)\end{array}$ & & & 14 & .08 \\
\hline$T$ & $\begin{array}{l}\text { Transport POL } \\
\text { Products }\end{array}$ & $\begin{array}{c}75,76,77,78,79,80, \\
81,83,86,87,89,90, \\
91,92,93,94 \\
(N=16)\end{array}$ & & & & 16 & .09 \\
\hline$T$ & $\begin{array}{l}\text { POL Site } \\
\text { Construction }\end{array}$ & $\begin{array}{c}6,9,10,21,25,26,27, \\
28,29,34,43 \\
(N=11)\end{array}$ & $\begin{array}{l}7,8 \\
(N=2)\end{array}$ & & & 13 & .07 \\
\hline
\end{tabular}




\begin{tabular}{|c|c|c|c|c|c|c|c|}
\hline & & $\begin{array}{c}K_{1} \\
K_{1}=145\end{array}$ & $\begin{array}{c}K_{2} \\
K_{2}=22\end{array}$ & $\begin{array}{c}k_{3} \\
\mathbf{x}_{3}=3\end{array}$ & $\begin{array}{c}K 4 \\
K=5\end{array}$ & $\begin{array}{l}\text { Total N } \\
\text { of Items }\end{array}$ & 8 \\
\hline $\mathbf{s}$ & First Aid & 148, $\underset{(N=3)}{150,156}$ & $\begin{array}{c}153,155 \\
(\dot{N}=2)\end{array}$ & $\begin{array}{c}154 \\
(N=1)\end{array}$ & & 6 & .03 \\
\hline$F$ & Navigate & 125, $\underset{\substack{126 \\
(N=4)}}{127}, 129$ & & $\begin{array}{c}128 \\
(N=1)\end{array}$ & & 5 & .03 \\
\hline$S$ & NBC & $147, \underset{(N=4)}{149,151,} 152$ & $\begin{array}{l}146 \\
(N=1)\end{array}$ & & & 5 & .03 \\
\hline$W$ & Weapons & $\begin{array}{l}102,103,104,105,108, \\
109,110,114,115,116, \\
118,130,131 \\
(N=13)\end{array}$ & $\begin{array}{c}106,107,111, \\
112,113,117 \\
(N=6)\end{array}$ & & . & 19 & .11 \\
\hline F & $\begin{array}{l}\text { Field } \\
\text { Techniques }\end{array}$ & 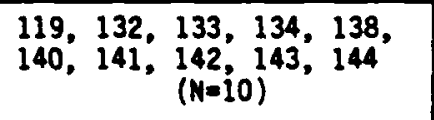 & $\begin{array}{l}139 \\
(M=1)\end{array}$ & $\begin{array}{l}145 \\
(N=1)\end{array}$ & & 12 & .07 \\
\hline$F$ & Communi cations & $\begin{array}{c}123,124 \\
(\dot{N}=2)\end{array}$ & & & & 2 & .01 \\
\hline$w$ & $\begin{array}{l}\text { Antitank/ } \\
\text { Antiair Heapons }\end{array}$ & 120, ${ }_{(N=3)}^{121,}{ }^{122}$ & 135, $\underset{(N=3)}{136,137}$ & & & 6 & .03 \\
\hline$S$ & $\begin{array}{l}\text { Customs and } \\
\text { Laws }\end{array}$ & $\begin{array}{c}158,160,161,162,163, \\
164,165,172,174 \\
(N=9)\end{array}$ & $\begin{array}{c}171,173 \\
(N=2)\end{array}$ & & $\begin{array}{c}157,159 \\
(N=2)\end{array}$ & 13 & .08 \\
\hline F & Orive (Operate) & 166, $\underset{(N=3)}{168,} 169$ & $\begin{array}{c}167,170 \\
(\dot{M}=2)\end{array}$ & & $\begin{array}{c}175 \\
(N=1)\end{array}$ & 6 & .04 \\
\hline $\mathbf{F}$ & $\begin{array}{l}\text { Preventive } \\
\text { Maintenance }\end{array}$ & $\begin{array}{c}101 \\
(N-1)\end{array}$ & & & & 1 & .005 \\
\hline$T$ & \begin{tabular}{|l|} 
Personnel/ \\
Organization \\
Clothing/Indiv. \\
Equipment
\end{tabular} & $\begin{array}{c}1,2,3,4,5,6,7,8,9, \\
10,11,12,13,14,15, \\
16,17,18,20,21,22, \\
23,24,25,26,27,28, \\
29 \\
(N=28)\end{array}$ & & . & $(N=1)$ & 29 & .17 \\
\hline$T$ & $\begin{array}{l}\text { Supply } \\
\text { Administration }\end{array}$ & $\begin{array}{l}31,32,33,34,35,37, \\
38,41,42,43,44,45, \\
46,47,48,49,50,51, \\
52,53,54,55,56,58, \\
73,74,76,77,79,80, \\
81,82,87,88,89,90, \\
91, \quad(N=37)\end{array}$ & $(N=2)$ & $\begin{array}{c}30 \\
(N-1)\end{array}$ & & 40 & .23 \\
\hline$T$ & Supply Storage & $36,85 \quad(N=2)$ & $\begin{array}{c}84 \\
(N=1)\end{array}$ & . & & 3 & .02 \\
\hline$T$ & $\begin{array}{l}\text { Property Book } \\
\text { Account ing }\end{array}$ & $\begin{array}{c}39,59,60,61,63,64, \\
65,66,67 ; 68,70,75 \\
(\dot{N}=12)\end{array}$ & $\begin{array}{r}62,69 \\
(N=2)\end{array}$ & & & 14 & .08 \\
\hline$T$ & $\begin{array}{l}\text { Unit Supply } \\
\text { Management }\end{array}$ & $40,57,71,72,83$ & & & & 5 & .03 \\
\hline$T$ & Unit Armory & $\begin{array}{l}92,93,94,95,96,97, \\
98,99,100 \\
(N=9)\end{array}$ & & & & 9 & .05 \\
\hline
\end{tabular}




\begin{tabular}{|c|c|c|c|c|c|c|c|}
\hline & & $\begin{array}{c}K_{1} \\
K_{1}=148\end{array}$ & $\begin{array}{c}K_{2} \\
K_{2}=18\end{array}$ & $x_{3=13}^{k 3}$ & $k_{4}^{k 4}$ & $\begin{array}{l}\text { Total n } \\
\text { of Items }\end{array}$ & $x$ \\
\hline $\mathbf{s}$ & First Aid & $159, \underset{(N=4)}{161,164,} 166$ & $\begin{array}{c}163,165 \\
(N=2)\end{array}$ & & & 6 & .03 \\
\hline $\mathbf{F}$ & $\begin{array}{c}\text { Navigate } \\
\text {. }\end{array}$ & 152, $\underset{(N=4)}{153,154,}, 155$ & & $\begin{array}{c}156 \\
(N=1)\end{array}$ & & 5 & .03 \\
\hline$s$ & NBC & 158, $\underset{(N=3)}{160,162}$ & $\begin{array}{c}157 \\
(N=1)\end{array}$ & & & 4 & .02 \\
\hline$W$ & Heapons & $167, \underset{(N=3)}{168,} 169$ & & & & 3 & .02 \\
\hline $\mathbf{F}$ & $\begin{array}{l}\text { Field } \\
\text { Techniques }\end{array}$ & 170, $\underset{(\dot{N}=4)}{171,172,173}$ & & & & 4 & .02 \\
\hline$F$ & Communications & $\begin{array}{c}150,151 \\
(\dot{N}=2)\end{array}$ & & & & 2 & .01 \\
\hline$S$ & $\begin{array}{l}\text { Customs and } \\
\text { Laws }\end{array}$ & $\begin{array}{c}174,175 \\
(N=2)\end{array}$ & & & & 2 & .01 \\
\hline$T$ & $\begin{array}{l}\text { Non-Meat Food } \\
\text { Preparation }\end{array}$ & $\begin{array}{l}19,20,21,24,26,27 \\
28,29,31,32,33,34, \\
35,37,39,40,41,42, \\
43,44,46,47,48,49, \\
52,53,54,57,58,59, \\
60,62,63,70,71,72, \\
73,74,75,76,109,117, \\
132,133,134,139 \\
\begin{array}{c}(N=46) \\
132\end{array}\end{array}$ & $\begin{array}{l}22,23,25, \\
51,77\end{array}$ & $\begin{array}{l}30 \\
(N=1)\end{array}$ & & 52 & .30 \\
\hline$T$ & $\begin{array}{l}\text { Meat } \\
\text { Preparation }\end{array}$ & $16,64,65,67,68,69,85$ & & & & 7 & .04 \\
\hline$T$ & Food Service & $\begin{array}{l}45,78,79,80,81,82, \\
83,84,86,87,88,89, \\
92,104,108,110,140, \\
143 \\
(N=18)\end{array}$ & 144 & & & 19 & .11 \\
\hline$T$ & $\begin{array}{l}\text { Food Service } \\
\text { Admintstration }\end{array}$ & $\begin{array}{l}90,91,93,95,96,100, \\
101,102,103,106,107, \\
111,112,113,114,118, \\
128,129,131,135,136, \\
138,141,142,145,146 \\
(N=26)\end{array}$ & $\begin{array}{l}94,97,98 \\
99,105,120, \\
137 \\
(N=7)\end{array}$ & - & & 33 & .19 \\
\hline$F$ & $\begin{array}{l}\text { Preventive } \\
\text { Maintenance }\end{array}$ & $147, \underset{(N=3)}{148,} 149$ & & & & 3 & .02 \\
\hline $\mathbf{T}$ & $\begin{array}{l}\text { General } \\
\text { Beverage }\end{array}$ & $\begin{array}{c}2,3,5,6,7,9,11,36, \\
38,55,56,66,115,116, \\
119,121,122,124,125, \\
126,127,130 \\
(N=22)\end{array}$ & 4,8 & $\begin{array}{l}1,10,12, \\
13,14,15, \\
17,18,50, \\
61,123 \\
(N=11)\end{array}$ & & 35 & .20 \\
\hline
\end{tabular}



Three factor solution for functional categories

Batch A

$\underline{118}$

mos Spectfic

Navigate (15 items)

Weapons (21)

Field Techniques (51)

Communications (8)*

Antitank/Anti af r (13)

Custom \& Law (13)
Drive

Drive (1 item)

First Aid (10 itens) *

MBC (5)

Variance

.35

.17

.17

- Factor loadings of .52 in MOS Specific and .50 in Drive.

- Factor loadings of .47 in Common, .38 in Mos Spectfic, and .36 in Drive.

\section{Self-propelled}

mos spectifte

Navigate (6)

Weapons (14)

Field Techniques (10)

Prp/Op/Mnt Howtz/Animo (56)

Op Howtz Sight/Ail ignment Dev (18)
Coming

First Aid (6)* NBC (7)

Communication (6)

Custom \& 1 aw (8)

orive (4)

Vart ance

.25

* Factor loadings of .43 in Common and .37 in MOS Specific. 
mos Specific

Navigate (6 itens)

NBC (7)

Communication (6)

Prep/0p/Mnt Howtz/Anmo (69)

Op Howt 2 Sights/Al igmment Dev (25) Custom \& Law (13)

Variance

.27

$31 \mathrm{C}$

mos Specific

Gener ators (12)

TTY Station \& Net Ops (69)

Maintain TTY El ectronic Equip (8)

Op TTY Electronic Equip (25)

Inst TTY Elec Equip (13)
Conmon

First Ald (6 items)

Weapons (14)

Field Techniques (1)

Custom \& Law (8)

Drive (4)

.23

Common

First Aid (10)*

MBC (8)

Weapons (3)

Field Techniques (6)

Antitank/Antiafr (5)

Custom \& Law (4)

Orive (4)

\section{Antitank/Antiair}

Antftank/Antiair (1 items)

.10

Other

Navigate (4)

Preventive Maint. (3)

Vehicle Op \& Recovery (1)

Variance

.22

.17

. .10

* Factor loadings of .53 in Common and .43 in mOS Specific.

* Factor loadings of .45 in Common and .43 in MOS Specific.

** Factor loadings of .44 in MOS Specific, .43 in Common and -.49 in Other. 
638

Mos Specific

Drive (25 items)

Preventive Maintenance (6)

Electrical Sys (21)

Brake/Steer/Susp Sys (43)

Vehtcle op \& Recovery (5)

Fuel/cooling Lubricating (32)

Vartance

.28
Common

MBC (3 itens)

Weapons (4)

Comunication (1)

Custom \& Law (7)

.18
Field

First Aid (6 items)

Navigate (10)

Field Techniques $(9)$ *

- Factor loadings of .55 in Field and .47 in Common.

640

Mos Spectific

Mavigate $(10)^{*}$

$\operatorname{MBC}(7)$

Field Techniques (12)

Drive (78)

Preventive Maintenence (4)

Venicle op \& Recovery (5)

Variance

$.26^{\circ}$

Commen

First Aid (4)

Communication (1)

Antitank/Antt air (1)

.14

Hecoons

Heapons (5)

Customs \& Law (1)

- Factor loadings of .52 in mos Spectfic and .42 in Common.

* Factor Inadings of .32 in Heapons, .29 in mos Specific and .24 in Common. 
IIL

mos Specific

Files/forms Managenent (19 items) Supv/Coord (1)*

Correspondence (52)

Cl assified Materials (4) wt
Common

First Aid (4 itens) Navigate (4)

MBC (3)

Weapons (5)

Field Techniques (2)

Antitank/Antfatr (2)

Orive (5)
Variance

.16
.14

.09

- Factor loadings of .40 in mos Specific and .55 in Common.

- Factor loadings of .52 in MOS Specific and -.44 in Communication.

* Factor loadings of .44 in Comon and .48 in mos Specific.

Factor loadings of .22 in Comm, .10 in MOS Specific and .06 in Communication.

$91 \mathrm{~A}$

- ins spectific.

First Ald (5)

Drive (9)

Cl infc/Ward Treatment/Care (89)

Clinic/Ward Housekeeping (15)

Cl inic/Ward Management (14)

General Medical Knowledge (36)

Vari ance

.31

.13

.11
Custon 8 :ar

Custon \& Law (1).

MBC (4)

Field Techntques (1)

- Factor loadings of .32 in Common and -.59 in Customs \& Lan. 
95B

Common

First Aid (16 items)

Navigate (8)

MBC (9)

Weapons (8)

Field Techniques (8)

Communication (5)

Customs \& Law (4)

Drive (10)

Preventive Mains (1)

Vehicle Op \& Recovery (1)*

Variance

.23
MOS Specific

Responding to Al arms (7 items) Conduct MP Procedures (46)

Patrol Duties (11)
Antitank/Antfair

Antitank/Antiair (5 items)

.16

.08

- Factor loadings of .35 in Common and -.46 in Antitank/Antiair.

61 
Appendix D

Batch A Three Factor Solution for Functional Categories 
Three factor solution for functional categories

Batch Z

128

\section{Common}

First Aid (11 items)

NBC (10)

Communications (9)

Antitank/Antiair (6)

Custom Law (12)

Orive (Op \& Maint) (7)

Preventive Maintenance (2)

Variance

.23

* Factor loadings of .65 in MOS Specific and .47 in Common.

$\underline{16 S}$

Pres

Communication (10)

Drive (10)

Preventive Maintenance (5)

Redeye (24)

Stinger (25)
Heapons (15)

\section{moS Specific}

Navigate (15 items)

Field Techniques (32)*

Bridging (10)

Field Fortifications (13)

Construction Tools \& Mat (5)

Construction (4)

Rigging (11)

Demolition (11)

. .21

\section{Supervision}

Unit Personnel Mgt \& Sup (1 item)

.07

Cominon

Antitank/Antiair (20)

TADOS (9)

Navigate (14)

.18

Vart ance

.18

- Factor loadings of .53 in Common and .42 in MOS Specific
First Aid (10)

NBC (4)*

Heapons (4)

Field Techniques (12)

Custom \& Law (2)

.17 
moS Specific

Preventive Maintenance (41 items)
TOW Components \& ?est Comp (37)
TOW Training Equip (10)
Dragon Components (23)
Dragon Test Simulators (13)

Common

First Aid ( 9 itens) Navigate (11) NBC (3)

We apons (5)

Communication (5)

Ant ft ank/Ant 1 air (6)

Custom \& Law (2)

Drive $(6)$ *

Variance

.28

- Factor loading of .45 in Common and .55 in MOS Specific.

518
Conson

First Aid (5)

NBC (4)

Field Techniques (14)

Communteation (3)

Field Fortifications (2)

Rigging (6)

Customs \& Laws (7)

Variance

.23
Antitank/Ant tair (4) mos Spectfic

Navigate (8)

Generators (2)

Construction Tools \& Mat. (17)* Construction (62)

Math (8)

Demolition (12) *

\section{Field Techniques}

Field Techniques (4 items)
.09

\section{Pincs}

Weapons (3)

Drive (5)

Preventive Maintenance (1)

* These items loaded .61 on MOS Specific and .46 on Common.

* Factor loadings of .41 in MOS Specific, .38 in Common and .35 in PMCS.

* Factor loadings of .71 in PMCS and .43 in mos spectfic. 
SAE

\section{Mos Specific}

First Aid (7 items) Decontamination Equipment (14) NBC (10)

Chemical/Biological/

Radiological Operations

Variance

.22

55B

Comon

First Aid (5)*

Navigate (9)

NBC (5)

Weapons (5)

Communication (4)

Drive (7)

Preventive Maintenance (3)

Vartance

.26
Pincs

Drive ( 3 ttens)

Preventive Maintenance (9)

Generators (3)

.16

Mos Specific

Antitank/Antiair (9)

Ammunition (33)**

Demolition (10)

Ammo Markings (57)

Storage/Transp. Signs (10)

Anmo Administration (11)

\section{Comon}

Heapons ( 8 items) Field Techniques (14 Antit ank/Antiair (4) Custans \& Law (11) Navigate (18)

.16

\section{Field Techniques}

Field Techniques (6) Customs \& Law (7)

- Factor loadings of .64 in Common and .50 in Field Techniques.

* Factor loadings of .61 in common and .50 in Field Techniques.

* Factor loadings of .70 in MOS Specific and .53 in Field Skitis. 
$67 N$

MoS Specific

Communication (5 items)

Hel tcopter Maintenance (107)

Aircraft Maint Admin (13)

Aircraft Refueling - (4)

Afreraft Maint Tools/Equip (8)

Vart ance

.18

764

\section{mos Specific}

POL Site Construction (13)

POL Site Operation (29)

POL Storage/Adm (42)

Equipment Maint (12)

POL Issue/Turn-in/Transfer (14)

Transport POL Products (16)

Variance .23
Common

Navigate (9 itens)

NBC (3)

Weapons (2)

Customs \& Law (6)

First Aid (5)

.14

Comon

First Aid (6)

Navigate (6)

Weapons (8)

Field Techniques (8)

Communication (3)

Antitank/Anttair (4)

Customs \& Laws (6)

Drive (6)*

.20
Field Techniques

Field Techniques ( 8 items) Antitank/Antiair (3)

Landing/Takeoff Sig (2)

.11

\section{Landing/Takeoff Signals}

Landing/Takeoff Sig (2)

- Factor loadings of .47 in Common and .41 in mos Specific. 


\section{Com}

First Aid (6 items)

Navigate (5)

NBC (5)*

Weapons (19)

Field Techniques (12)

Conmuntcation (2)

Antitank/Antiair (6)

Customs \& Law (13)

Drive (6)

Variance

.22 mos Spectific

Pers/Org Clothing/ Ind Equip (29 items) * Supply Administration (40)

Supply Storage (3)

Property Book Accounting (14)

init Suppiy Management (5)

- Factor loadings of .49 in both Common and MOS Specific.

* Factor loadings of .56 in MOS Specific and .43 in PMCS.

*actor loadings of .67 in MOS Specific and .41 in PicS.

948

\section{Mos Specific}

Mon-Meat Food Prep (52)

Meat Preparation (7)

Food Service (19)

Food Service Equip/Admin (33)

Gen Beverage/Food Prep (35)

Variance

.23
.16
Prics

Preventive Maint ( 2 item) Unit Armory (9)

Fleld Techniques

First Aid (6)

Navigate (5)

NBC (4)

Communication (2)

Preventive Maintenance (3)

.20
Weapons (3)

Field Techniques (4)

Custons \& Law (2) 